UC-25 Metallurgy and Ceramics (TID-4500, 15th Ed.)

\title{
PROGRESS ON CERAMIC COATED FUEL PARTICLES AT BATTELLE
}

\author{
Presented at the AEC Information Meeting \\ Held at \\ Battelle Memorial Institute \\ July 12,1960
}

September 16,1960

Prepared by Battelle Memorial Institute

Contract No. W-7405-eng-92 for

UNITED STATES ATOMIC ENERGY COMMISSION 


\section{DISCLAIMER}

This report was prepared as an account of work sponsored by an agency of the United States Government. Neither the United States Government nor any agency Thereof, nor any of their employees, makes any warranty, express or implied, or assumes any legal liability or responsibility for the accuracy, completeness, or usefulness of any information, apparatus, product, or process disclosed, or represents that its use would not infringe privately owned rights. Reference herein to any specific commercial product, process, or service by trade name, trademark, manufacturer, or otherwise does not necessarily constitute or imply its endorsement, recommendation, or favoring by the United States Government or any agency thereof. The views and opinions of authors expressed herein do not necessarily state or reflect those of the United States Government or any agency thereof. 


\section{DISCLAIMER}

Portions of this document may be illegible in electronic image products. Images are produced from the best available original document. 


\section{TABLE OF CONTENTS}

$\underline{\text { Page }}$

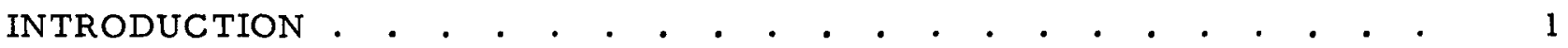

PRESENTATIONS AND DISCUSSIONS AT MEETING . . . . . . . . . . $\quad 2$

Background Information . . . . . . . . . . . . . . . 2

Coated-Particle Fabrication . . . . . . . . . . . . . . . 3

Fuel-Element Fabrication . . . . . . . . . . . . . . . . 15

In-Pile Tests . . . . . . . . . . . . . . . . . . . . 19

Final Remarks • • . . . . . . . . . . . . . . . . . 30

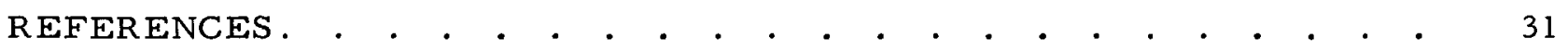




\section{PROGRESS ON CERAMIC COATED FUEL PAR TICLES \\ AT BATTELLE}

\section{INTRODUCTION}

W. S. Diethorn

Fuel particles individually clad with an impervious coating and dispersed in a suitable matrix may have many important applications in high-temperature fuel-element technology. A number of sites are investigating this fuel concept. On July 12, 1960, an information meeting on coated fuel particles was held at Battelle Memorial Institute at the request of the Commission. The purpose of the meeting was to review the work on nonmetallic coatings for fuel particles and to encourage an informal discussion of this fuel concept in high-temperature fuel-element applications. B. W. Dunnington of Battelle was moderator of the meeting. Representatives from the following organizations attended:

\section{Organization}

AEC

Aerojet

Battelle

General Atomic

GE-ANPD

General Nuclear Engineering Corporation

Lawrence Laboratory

Oak Ridge National Laboratory

Sanderson \& Porter

\section{$\underline{\text { Representative }}$}

R. F. Kirkpatrick (Washington)

M. F. Whitman (Washington)

J. Martin (Oak Ridge)

V. E. Adler (New York)

J. Wise (New York)

J. F. Weissenberg (LAROO)

H. Reynolds (Savannah River)

R. L. Pearson

B. W. Dunnington

W. S. Diethorn

J. M. Blocher

W. C. Riley

G. E. Raines

G. R. Tully

L. R. Zumwalt

C. C. Browne

W. A. Maxwell

C. Z. Hoenig

W. R. Grimes

L. Stoughton 
This report, which summarizes the Battelle contribution to this meeting, is being issued because the information it contains is not available elsewhere in a concise form to the general readers of atomic-energy literature. Hitherto, this information has been presented only in scattered progress reports. Some of the discussion following the presentations in this meeting is also given because the questions and answers add information about the subject.

\section{PRESENTATIONS AND DISCUSSIONS AT MEETING}

\section{Background Information}

W. S. Diethorn

About 500, 000 particles of fully enriched $\mathrm{UO}_{2}$, each coated with $40 \mu$ of aluminum oxide, are currently being irradiated at $1500 \mathrm{~F}$ in the Battelle Research Reactor. After 70 days for a burnup of 3 per cent of the uranium-235, or 30,000 MWD/T of uranium, these particles continue to show excellent fission-gas retention. In the session this morning we are going to review the work on alumina-coated $\mathrm{UO}_{2}$ particles and, in addition, the less extensive work on carbon-coated $\mathrm{UC}_{2}$. Only the alumina-coated $\mathrm{UO}_{2}$ has been tested in-pile.

If an impervious coating with good high-temperature properties can be applied to fuel particles, a dispersion of the se particles in a matrix offers a promising solution to several high-temperature fuel-element problems. Among the se are fission-product release, corrosion, and fuel migration. Battelle has been investigating coated fuel particles for several groups, including Sanderson \& Porter, General Atomic, and Aerojet. This presentation will not include studies of metal-coated particles.

The history of our coated particle work may be of some interest to you. About 3 years ago a ceramic process of coating $\mathrm{UO}_{2}$ particles with $\mathrm{Al}_{2} \mathrm{O}_{3}$ was studied. (1) In this process $\mathrm{UO}_{2}$ particles are spray coated with a slip containing $\mathrm{Al}_{2} \mathrm{O}_{3}$, compacted, and then sintered. Laboratory evaluation of the particles was encouraging. In early 1959 a second method, the so-called fluidized-bed method, of coating $\mathrm{UO}_{2}$ particles with $\mathrm{Al}_{2} \mathrm{O}_{3}$ was developed. In this technique $\mathrm{UO}_{2}$ particles are coated with $\mathrm{Al}_{2} \mathrm{O}_{3}$ by reacting $\mathrm{Al}_{2} \mathrm{Cl}_{6}$ and water vapor in a fluidized bed of the particles. Laboratory evaluation of this coated material showed satisfactory behavior, encouraging a small rate of effort directed toward fuel-element applications. In late 1959 it was decided to investigate the coated fuel particle as one approach to the problem of fission-product release from fueled graphite in Sanderson \& Porter's Pebble Bed Reactor. The core of the helium-cooled Pebble Bed Reactor consists of a bed of several hundred thousand fueled-graphite spheres. (2) Promising surface coatings have been studied for the retention of fission products in the spheres. The advantages of individually coated fuel particles suggested that a study be made of coated fuel particles in Battelle's fuelelement evaluation program for Sanderson \& Porter. Uranium dioxide particles coated with $\mathrm{Al}_{2} \mathrm{O}_{3}$ by the fluidized-bed process were selected for study. By early April of this year, this material had passed successfully laboratory evaluations, and was incorporated into graphite spheres and irradiated in a high-temperature capsule experiment in the BRR.

(1) References at end. 
The potential advantages of the coated-fuel-particle concept, and in particular the encouraging results with $\mathrm{Al}_{2} \mathrm{O}_{3}-\mathrm{UO}_{2}$, has generated considerable interest in other types of coated fuel particles such as carbon-coated $\mathrm{UC}_{2}$. A carbon coating is readily applied to $\mathrm{UC}_{2}$ by the fluidized-bed process. Out-of-pile evaluation of this material is encouraging. Ir radiation of carbon-coated $\mathrm{UC}_{2}$ will await the completion of present out-of-pile evaluations.

The Battelle work on coated particles will be discussed under the following three topics:

(1) Coated-Particle Fabrication

(2) Fue1-Element Fabrication

(3) In-Pile Tests.

\section{Coated-Particle Fabrication}

John M. Blocher, Jr.

It is a pleasure to review our experience in the coating of $\mathrm{UO}_{2}$ and $\mathrm{UC}_{2}$ fuel particles. My presentation will cover the history of our work in chemical vapor deposition, describe $\mathrm{Al}_{2} \mathrm{O}_{3}$ and carbon coatings which have been applied by this technique, show equipment for laboratory-scale preparation, and discuss out-of-pile evaluation results.

Chemical vapor deposition can be defined as the formation of a solid deposit by chemical reaction of vapors at a heated surface. A wide variety of reactions are available for the chemical vapor deposition of metals, oxides, nitrides, borides, carbides, and silicides. Battelle has been active in this field since 1938, both in the preparation of refractory coatings and in the preparation of high-purity refractory metals. In 1957 , while considering chemical vapor deposition in a fluidized bed of seed particles for the preparation of high-purity metals, Dr. Joseph Oxley, of our group, suggested that this technique would be ideally suited for coating nuclear fuel particles. Dense coatings would be expected to provide good fission-product retention and prevent contact between fuel and corrosive environments.

The first task undertaken was the difficult one of coating micron-sized $\mathrm{UO}_{2}$ particles with tungsten. In this case, the $\mathrm{UO}_{2}$ powder tended to coat as agglomerates rather than as discrete particles. However, it is possible to coat discrete particles in diameters greater than about $20 \mu$ with ease. Subsequent work demonstrated that we could coat fuel particles with carbon, chromium, chromium-nickel alloys, molybdenum, nickel, niobium, niobium-vanadium alloys, tantalum, $\mathrm{Al}_{2} \mathrm{O}_{3}, \mathrm{Cr}_{2} \mathrm{O}_{3}, \mathrm{NbC}, \mathrm{SiC}$, and $\mathrm{ZrO}_{2}$. In addition, limited work on the deposition of zirconium has shown promise. Chemical vapor deposition of these coatings may be carried out in a rotary kiln, on a vibrating pan, or in a fluidized bed. We prefer to use the fluidized bed because it yields a more uniform product and, under proper conditions, avoids the formation of agglomerates. 


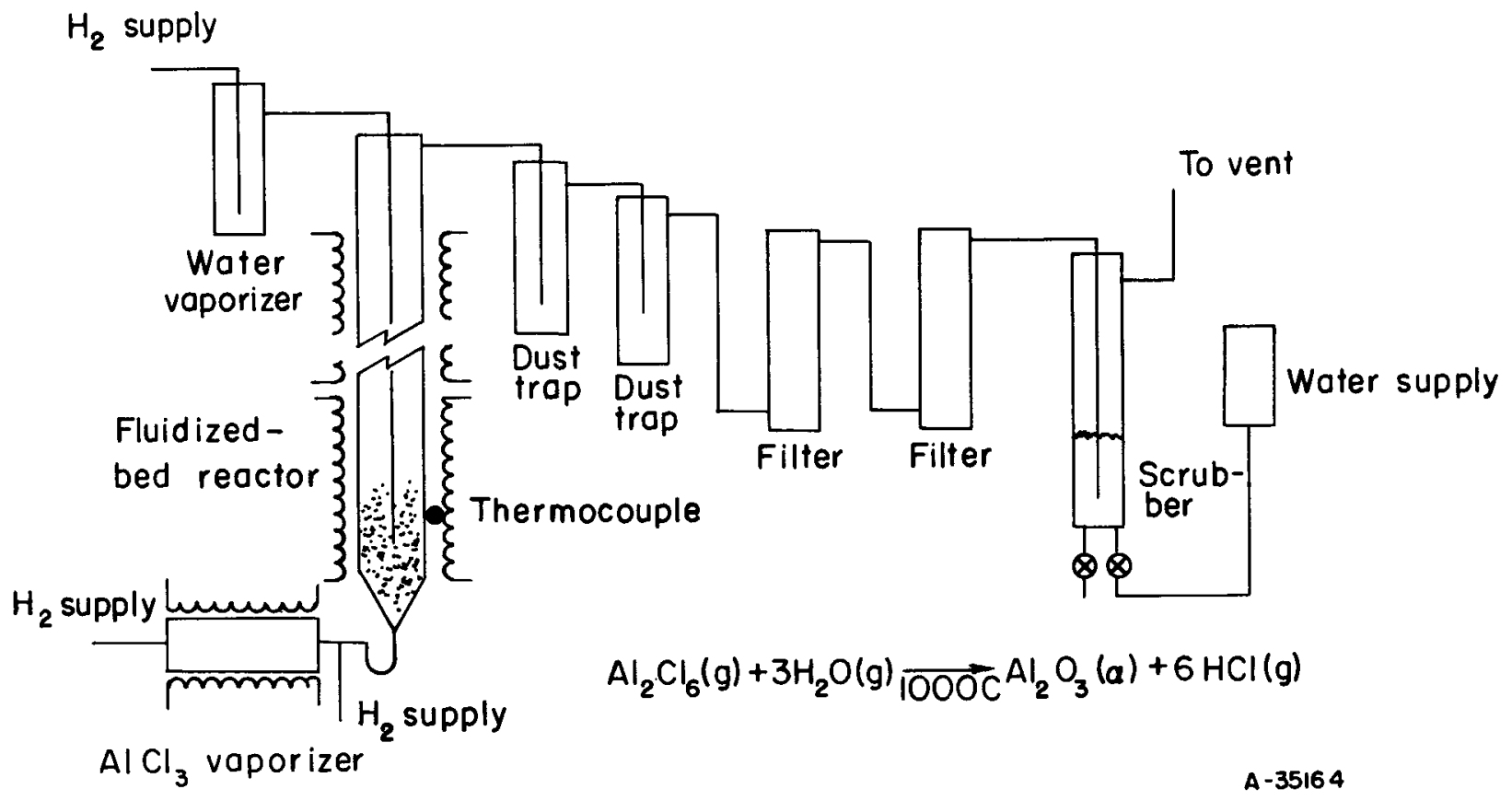

FIGURE 1. SCHEMATIC DIAGRAM OF APPARATUS FOR THE LABORATORY PRODUCTION OF $\mathrm{Al}_{2} \mathrm{O}_{3}$-COATED UO 
$\underline{\mathrm{Al}_{2} \mathrm{O}_{3}-\mathrm{UO}_{2}}$

The work which has led directly to this meeting today started in March of 1959 with our deposition of $\mathrm{Al}_{2} \mathrm{O}_{3}$ on $\mathrm{UO}_{2}$ as a reaction barrier. The first few runs were thought to be unsuccessful since there was no change in appearance of the $\mathrm{UO}_{2}$ powder. It went in black and came out black. Closer examination revealed that the coating was indeed present as dense, transparent alpha- $\mathrm{Al}_{2} \mathrm{O}_{3}$. In January, 1960, we began to prepare $\mathrm{Al}_{2} \mathrm{O}_{3}$-coated $\mathrm{UO}_{2}$ as part of Sanderson \& Porter's fuel-element evaluation program at Battelle. Later on in the session this morning Gil Raines will discuss the excellent irradiation performance of this material.

Figure 1 is a schematic diagram of apparatus for the deposition of $\mathrm{Al}_{2} \mathrm{O}_{3}$ on $\mathrm{UO}_{2}$ particles. The reaction is carried out in an externally heated quartz tube provided with a conical bottom to support the bed of powder. Hydrogen, partially saturated with aluminum chloride, constitutes the major portion of fluidizing gas. A separate stream of hydrogen is passed through a water vaporizer and through an axial tube which terminates in the lower part of the fluidized bed where mixing of the reactants occurs at a temperature of about $1000 \mathrm{C}$. A $100-\mathrm{g}$ batch size is convenient to work with and is adequate for our evaluation studies. With a $100-\mathrm{g}$ bed of $\mathrm{UO}_{2}$ powder in a 1-in. -diameter reactor, about one-half of the $\mathrm{Al}_{2} \mathrm{O}_{3}$ formed by hydrolysis is deposited on the particles, the other half is formed as a fine powder and is carried over into the traps. Progress of the hydrolysis is followed by titrating the $\mathrm{HCl}$ collected in the water scrubber. Figure 2 is a photograph of the apparatus set up in a laboratory hood.

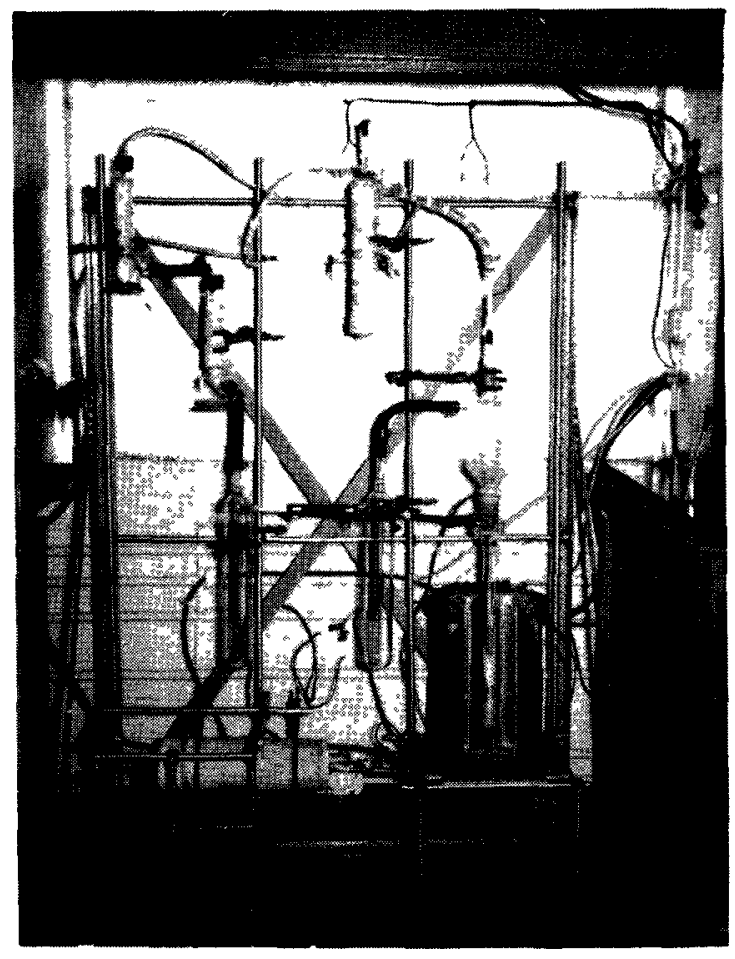

FIGURE 2. LABORATORY APPARATUS FOR THE PREPARATION OF $\mathrm{Al}_{2} \mathrm{O}_{3}$-COATED UO $\mathrm{U}_{2}$ PAR TICLES 


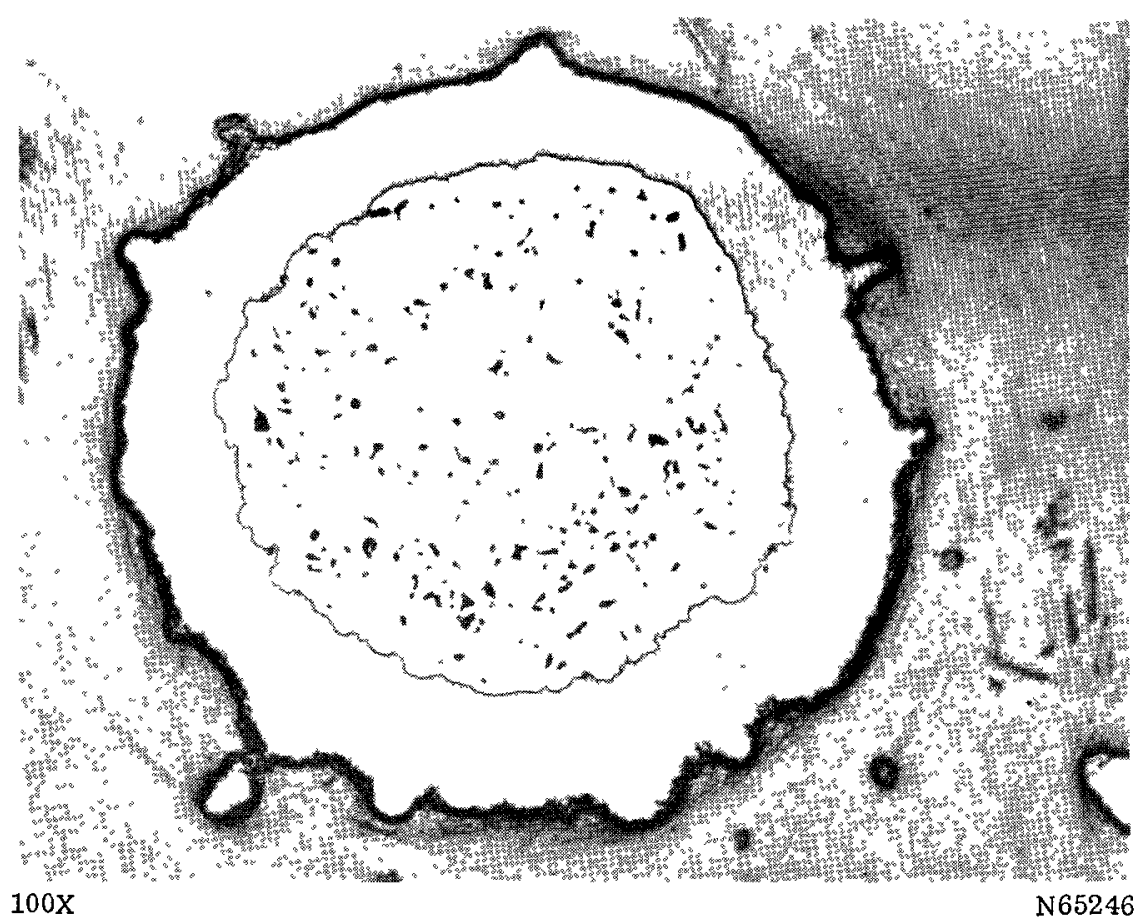

a. $\mathrm{UO}_{2}$ Partıcles With $20-\mu$ Coating

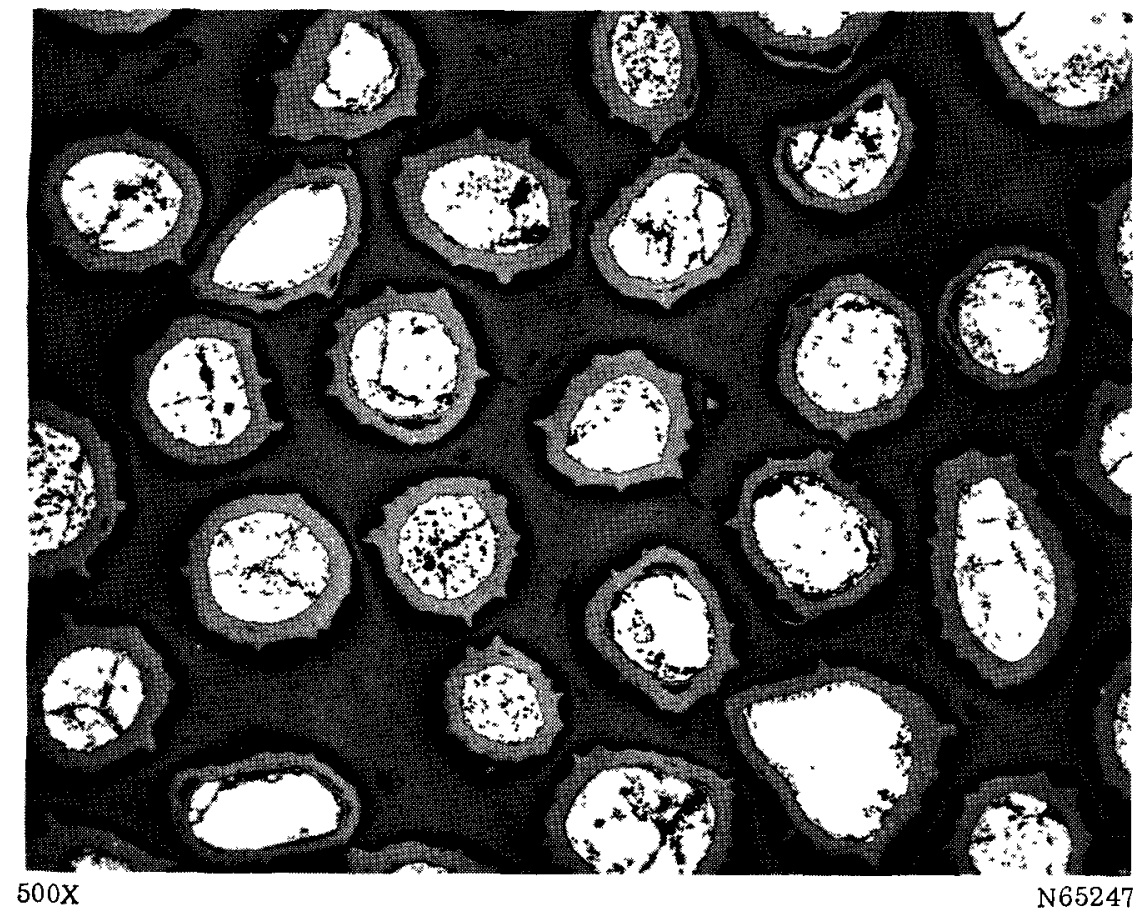

b. View of a Coated Particle

FIGURE 3. TYPICAL EXAMPLES OF $\mathrm{Al}_{2} \mathrm{O}_{3}$-COATED 100 TO $150-\mu \mathrm{UO}_{2}$ POWDER 
It should be pointed out that no effort has been made to increase the rate of coating formation to a maximum consistent with good coating properties. The highest rate of formation used in our work is $4 \mu$ per $\mathrm{hr}$. There is no apparent change in coating microstructure when materials prepared at this rate and lower rates are compared.

In work with coated powders at Battelle, we have used three sizes of fluidizedbed reactor, the 1-in. -diameter reactor mentioned above, a 2-in.-diameter reactor for preparation of laxger quantities of material, and a 5-in.-diameter pilot-scale reactor provided with facilities for the recirculation of hydrogen. It is interesting to note that this 5-in. - diameter reactor is practically a prototype for commercial units handling fully enriched powder, because the diameter must be limited to some value near 5 in. to avoid criticality problems. This limitation significantly affects the economics of the coating process. The cost of coating natural or slightly enriched material should be substantially less than that of coating enriched material because larger fluidized-bed reactors can be used.

Figure 3 shows 100 to $150-\mu \mathrm{UO}_{2}$ powder coated with $20 \mu$ of $\mathrm{Al}_{2} \mathrm{O}_{3}$. Figure 4 is an electron micrograph of the $\mathrm{Al}_{2} \mathrm{O}_{3}$ coating. The granular structure of the $\mathrm{UO}_{2}$ core is shown in the lower part of Figure 4. The dense alpha alumina coating is shown just above the $\mathrm{UO}_{2}$. Notice that there is no evidence of a grain structure in the $\mathrm{Al}_{2} \mathrm{O}_{3}$ at this magnification.

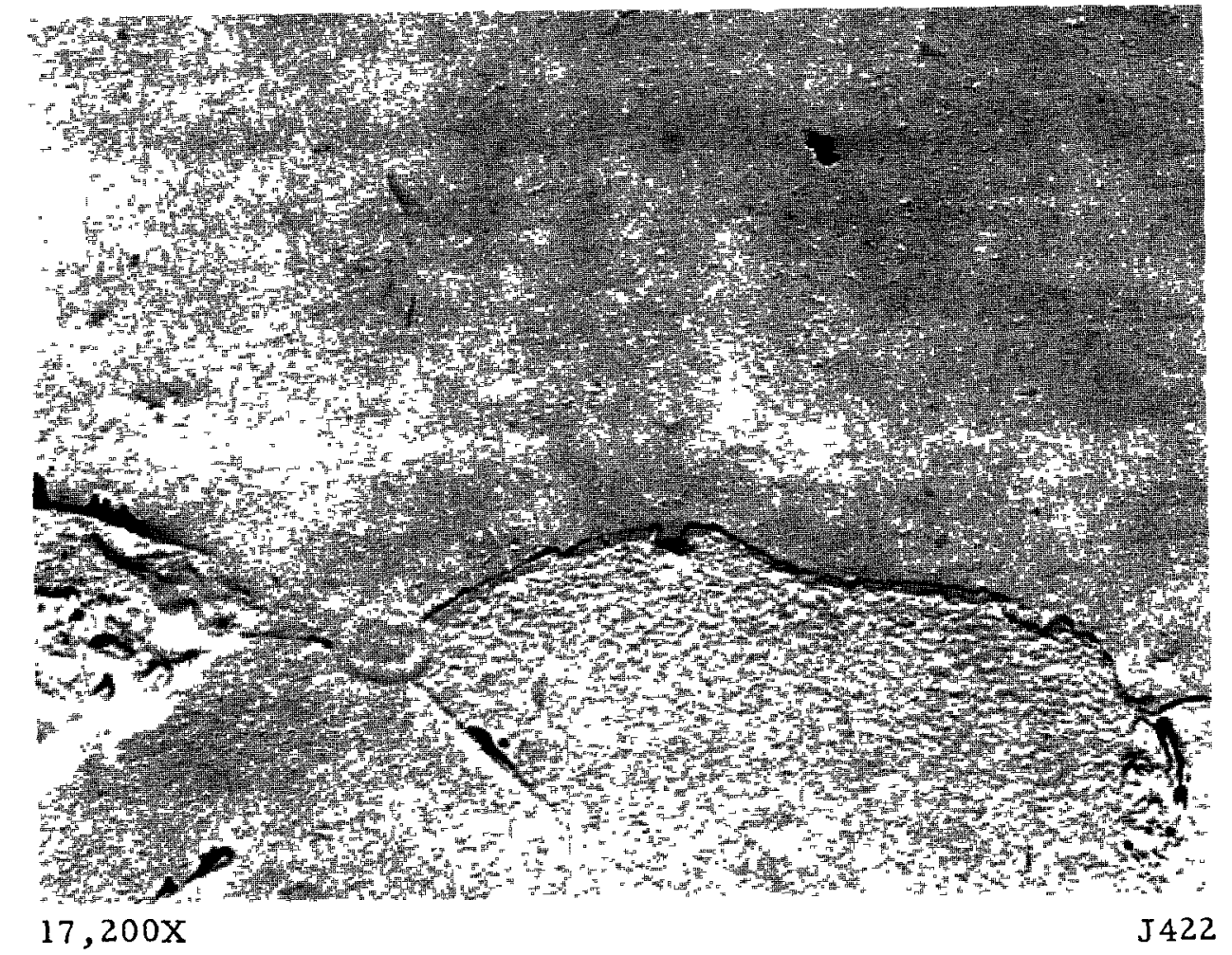

FIGURE 4. ELECTRON MICROGRAPH OF $\mathrm{Al}_{2} \mathrm{O}_{3}$ COATING ON UO 2

Laboratory evaluation of coated $\mathrm{UO}_{2}$ particles consists of air-oxidation tests, nitric acid leaching, measurements of uranium contamination, and neutron activation followed by postirradiation heating. Contamination is determined by counting the alpha radioactivity from a monolayer of the coated particles in an internal-sample proportional counter. An alpha assay is a more sensitive method of measuring uranium 
contamination than an air-oxidation test but does not distinguish among core uranium exposed by a crack in the coating, uranium on the outside surface of the coating, or uranium in the coating within $10 \mu$ of the coating surface. Fission-gas release is determined by heating the neutron-activated particles in flowing helium, absorbing the liberated xenon-133 in a charcoal trap, and monitoring the cumulative trap activity during the heat treatment.

Some representative results of the evaluation are summarized in Table 1. Comparison of the leach data for the first two lots shows the effect of coating-deposition temperature on coating porosity. Dense alpha alumina is deposited at $1000 \mathrm{C}$, but at $700 \mathrm{C}$ less dense gamma and kappa alumina are deposited. Lots 15638-13A and 15638-14C were very resistant to oxidation at $1000 \mathrm{C}$. Oxidation values in Table 1 are open to some question, however, because during the test with the fourth lot the platinum crucible gained weight equivalent to oxidation of 0.7 per cent of the $\mathrm{UO}_{2}$. Lot 16587-2 showed an increase in alpha activity after severe thermal cycling to $1370 \mathrm{C}$, but the results of an oxidation test at $650 \mathrm{C}$ appear to exclude coating failure during the the rmal cycling.

In preparation for the capsule irradiation of a graphite sphere fueled with $\mathrm{Al}_{2} \mathrm{O}_{3}$ coated $\mathrm{UO}_{2}$ the as-produced particles were neutron activated to determine postirradiation fission-gas release. About $10^{-4}$ of the xenon-133 in the particles was released during several hours at $2300 \mathrm{~F}$.

The coefficient of expansion of $\mathrm{UO}_{2}$ is somewhat greater than that of $\mathrm{Al}_{2} \mathrm{O}_{3}$. Accordingly, the coating is placed in tension as the particles are heated above the coating-deposition temperature. It is, therefore, of interest to determine the ratio of coating thickness to particle diameter necessary to withstand the thermal stress. This is being done with a series of batches containing 22 to $150-\mu$ coatings. The se samples will be alpha counted and oxidation tested before and after thermal cycling.

Other aspects of the performance of $\mathrm{Al}_{2} \mathrm{O}_{3}$-coated particles will be discussed by the other speakers this morning.

Carbon-Coated $\mathrm{UC}_{2}$

Pyrolytic-carbon coatings can be applied to uranium carbide by the fluidized-bed vapor-deposition technique. When a hydrocarbon is decomposed on a surface at temperatures of $1000 \mathrm{C}$ and above, a hard form of carbon commonly called "pyrolytic carbon" deposits with the planes of the graphitic rings usually lying parallel with the surface on which the deposition occurs. In contrast with the ordered structure of graphite, adjacent planes are randomly oriented. If the graphitic planes grow circumferentially on the fuel particles, the coating will be anisotropic.

Figure 5 is a schematic diagram of apparatus used to apply pyrolytic-carbon coatings to fuel particles. It is very similar to the apparatus used to produce $\mathrm{Al}_{2} \mathrm{O}_{3}$ coatings, except for the materials of construction. In carrying out the reaction at 1300 to $1400 \mathrm{C}$, a Mullite reactor is used. At higher temperatures, a carbon or graphite reactor is necessary. At $1350 \mathrm{C}$, carbon is deposited in our apparatus at a rate of $20 \mu$ per hr on 150 to $175-\mu \mathrm{UC}_{2}$ particles when the vapor feed consists of 10 to 20 volume per cent acetylene in an inert gas. 
TABLE 1. SUMMARY OF LABORATORY EVALUATION OF $\mathrm{Al}_{2} \mathrm{O}_{3}-\mathrm{COATED} \mathrm{UO} \mathrm{O}_{2}$ PARTICLES

\begin{tabular}{|c|c|c|c|c|c|c|c|c|}
\hline Lot & $\begin{array}{l}\text { Fuel Partıcle } \\
\text { Diameter, } \mu\end{array}$ & $\begin{array}{c}\text { Coatıng } \\
\text { Thickness, } \mu\end{array}$ & $\begin{array}{c}\text { Deposition } \\
\text { Temperature, C }\end{array}$ & Treatment & $\begin{array}{c}\text { Alpha Assay }{ }^{(a)} \text {, } \\
\text { cpm per } g \\
\text { of clad } \\
\text { particles }\end{array}$ & $\begin{array}{c}\text { Uranıum } \\
\text { Contamination } \\
\text { mg per } g \text { of } \\
\text { clad particles }\end{array}$ & $\underset{\text { per cent }}{\mathrm{UO}_{2}}$ Oxudızed $^{(c)}$ & $\begin{array}{l}\text { Uranium } \\
\text { Leached }^{(\Phi)}, \\
\text { per cent }\end{array}$ \\
\hline $15638-5$ & $149-250$ & 8 & 1000 & As prepared & -- & -- & -- & 0.3 \\
\hline $15638-8 A$ & $105-149$ & 8 & 700 & As prepared & -- & -- & -- & 65. \\
\hline $15638-13 A$ & $44-53$ & 9.5 & 1000 & $\begin{array}{l}16 \mathrm{hr} \text { at } 1000 \mathrm{C} \\
\text { in air }\end{array}$ & -- & -- & 0.1 & -- \\
\hline \multirow[t]{4}{*}{$15638-14 C$} & $44-53$ & 15 & 1000 & $\begin{array}{l}23 \mathrm{hr} \text { at } 480 \mathrm{C} \\
\text { in alr }\end{array}$ & -- & -- & 0.3 & -- \\
\hline & & & & $\begin{array}{l}+16.5 \mathrm{hr} \text { at } 1000 \mathrm{C} \\
\text { in air }\end{array}$ & -- & -- & 0.0 & -- \\
\hline & & & & $\begin{array}{l}+64 \mathrm{hr} \text { at } 1000 \mathrm{C} \\
\text { in air }\end{array}$ & -- & -- & 0.3 & -- \\
\hline & & & & $\begin{array}{l}+160 \mathrm{hr} \text { at } 1000 \mathrm{C} \\
\text { in air }\end{array}$ & -- & -- & 0.7 & -- \\
\hline $\begin{array}{l}\text { (Platınum } \\
\text { crucible) }\end{array}$ & -- & -- & -- & - & -- & -- & -- & -- \\
\hline $16587-1 B$ & $105-149$ & 20 & 1000 & As prepared & $7.3 \pm 1.3$ & 0.01 & -- & -- \\
\hline \multirow[t]{2}{*}{$16587-2$} & $105-149$ & $35-40$ & 1000 & As prepared & $1.4 \pm 1.0$ & 0.002 & -- & -- \\
\hline & & & & $\begin{array}{l}\text { Nine }(20 \mathrm{~min}) \\
\text { thermal cycles } \\
\text { to } 1370 \mathrm{C} \text { in air }\end{array}$ & $76 \pm 5.2$ & 0.1 & $0.0(5 \mathrm{hr}$ at $650 \mathrm{C})$ & \\
\hline
\end{tabular}

\footnotetext{
(a) Corrected for background.

(b) Corrected for counting geometry. Contamination assumed to be in top $10 \mu$ of coating.

(c) Per cent of $\mathrm{UO}_{2}$ in particles.

(d) Per cent of uranium leached by $1: 1 \mathrm{HNO}_{3}$ in $18 \mathrm{hr}$ at room temperature.
} 


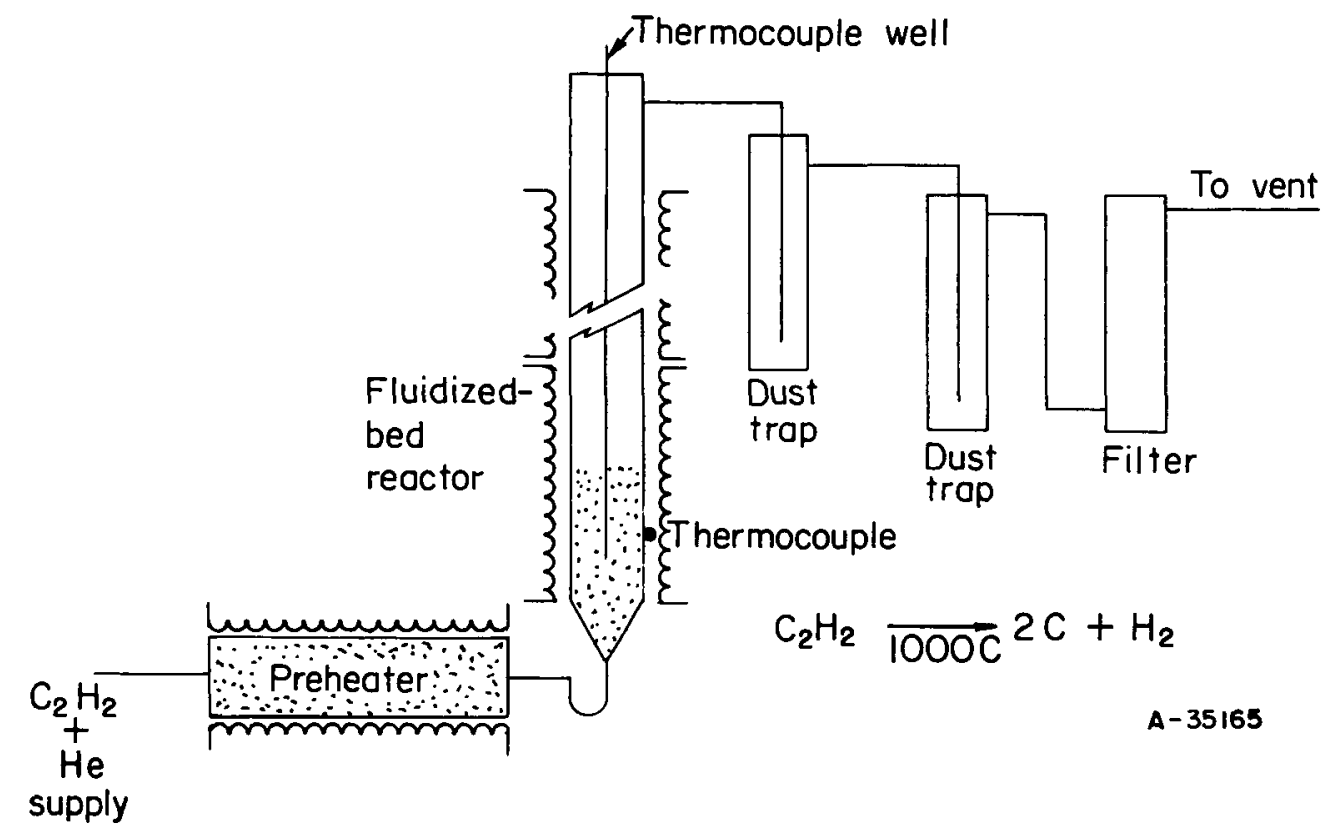

FIGURE 5. SCHEMATIC DIAGRAM OF AFPARATUS FOR THE PREPARATION OF CARBON-COATED UC ${ }_{2}$ 
Figure 6 shows 150 to $175-\mu$-diameter particles of $\mathrm{UC}_{2}$ coated with $80 \mu$ of pyrolytic carbon. Coating deposition temperature was $1350 \mathrm{C}$. The characteristic "onionskin" structure is barely discernible in the coating in Figure 6b. This structure may possibly result from the difference in the coefficients of expansion in the radial and circumferential directions coupled with weak interplanar bonding. The data in Table 2 show that the porosity of the carbon coatings is generally very low, and that the coatings can be ruptured by heating to temperatures in excess of the coating deposition temperature. For example, the release of xenon-133 increased sharply on postirradiation heating of Lot SPIC above the coating temperature. Alpha assays and leach tests on the other samples after nine 20-min thermal cycles between 300 and $2000 \mathrm{C}$ in argon also showed this same relationship between deposition temperature and coating failure. Coating failure undoubtedly occurs as the result of the large difference in the coefficients of expansion of $\mathrm{UC}_{2}\left(10 \times 10^{-6}\right.$ per C) and pyrolytic carbon $\left(2 \times 10^{-6}\right.$ per C).

There are several approaches to the thermal-stress problem at high temperature. One approach is to coat the fuel particle at a temperature higher than the maximum operating temperature expected in the coated-particle application. However, any rotation, relative to the shell, of a loose, nonspherical core on cooling after coating could result in thermal stresses at temperatures below the coating temperature as the particle is reheated. Another approach is to provide a layer of porous carbon adjacent to the $\mathrm{UC}_{2}$ to serve as a cushion for the expansion. It is believed that conditions can be found for the deposition of porous carbon of the desired structure. In the near future we plan to determine whether higher coating-deposition temperatures will extend the useful temperature range of the coating. We intend also to follow up some promising results on the modification of the basic pyrolytic carbon structure.

\section{Summary}

In summary, the following four points deserve emphasis:

(1) Dense, near-transparent coatings of alpha alumina can be applied to fuel particles by hydrolysis of aluminum chloride in a fluidized bed of $\mathrm{UO}_{2}$ powder particles. This coating provides good oxidation resistance and fission-gas retention.

(2) Pyrolytic-carbon coatings can be easily applied by the fluidized-bed process. The very low coefficient of expansion of pyrolytic carbon, its anisotropic character, and its poor radial strength are potential problems. Several promising approaches to these problems are available.

(3) Chemical vapor deposition offers the promise of custom-built massproduced nuclear-fuel particles. A wide variety of materials can be deposited singly, simultaneously, or alternately. Void structures, burnable poisons, or fertile materials for breeding can also be deposited. 


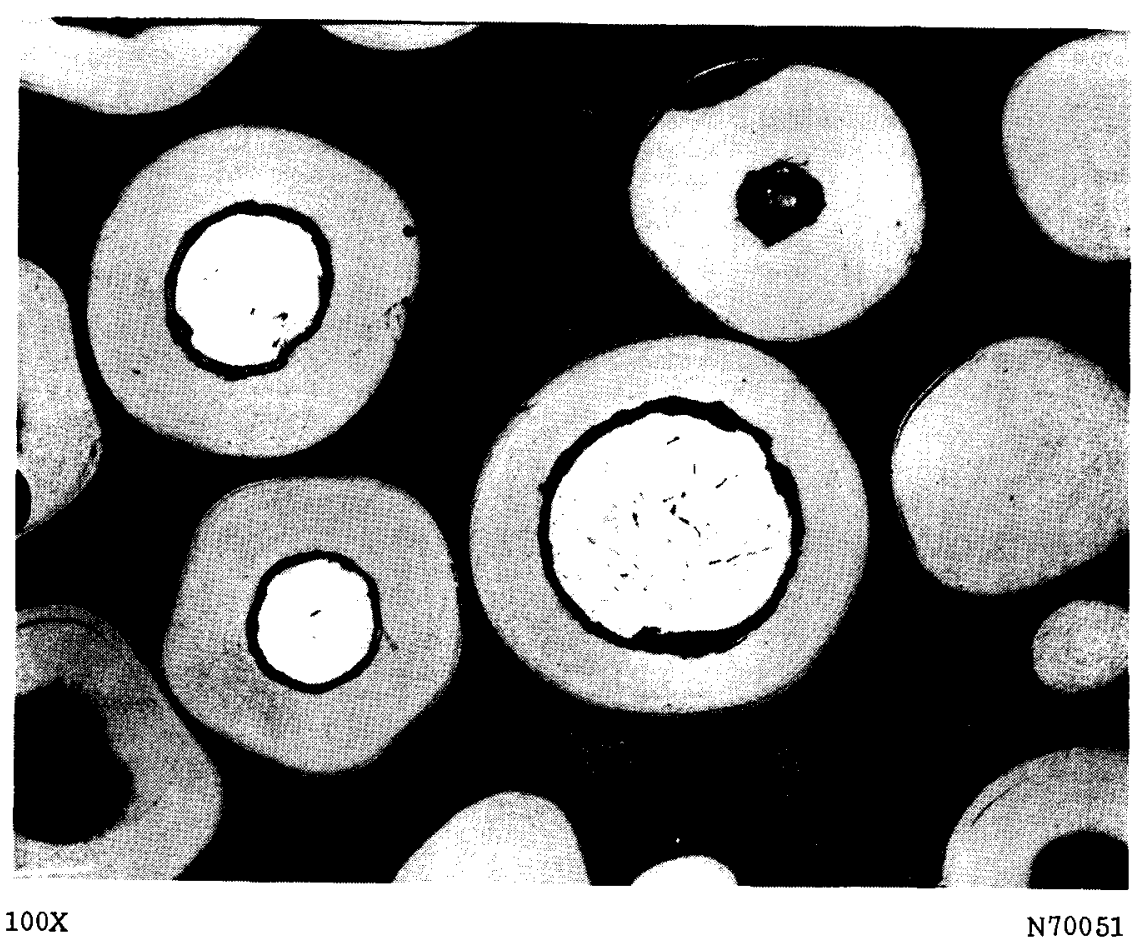

a. Typical Appearance of Particles

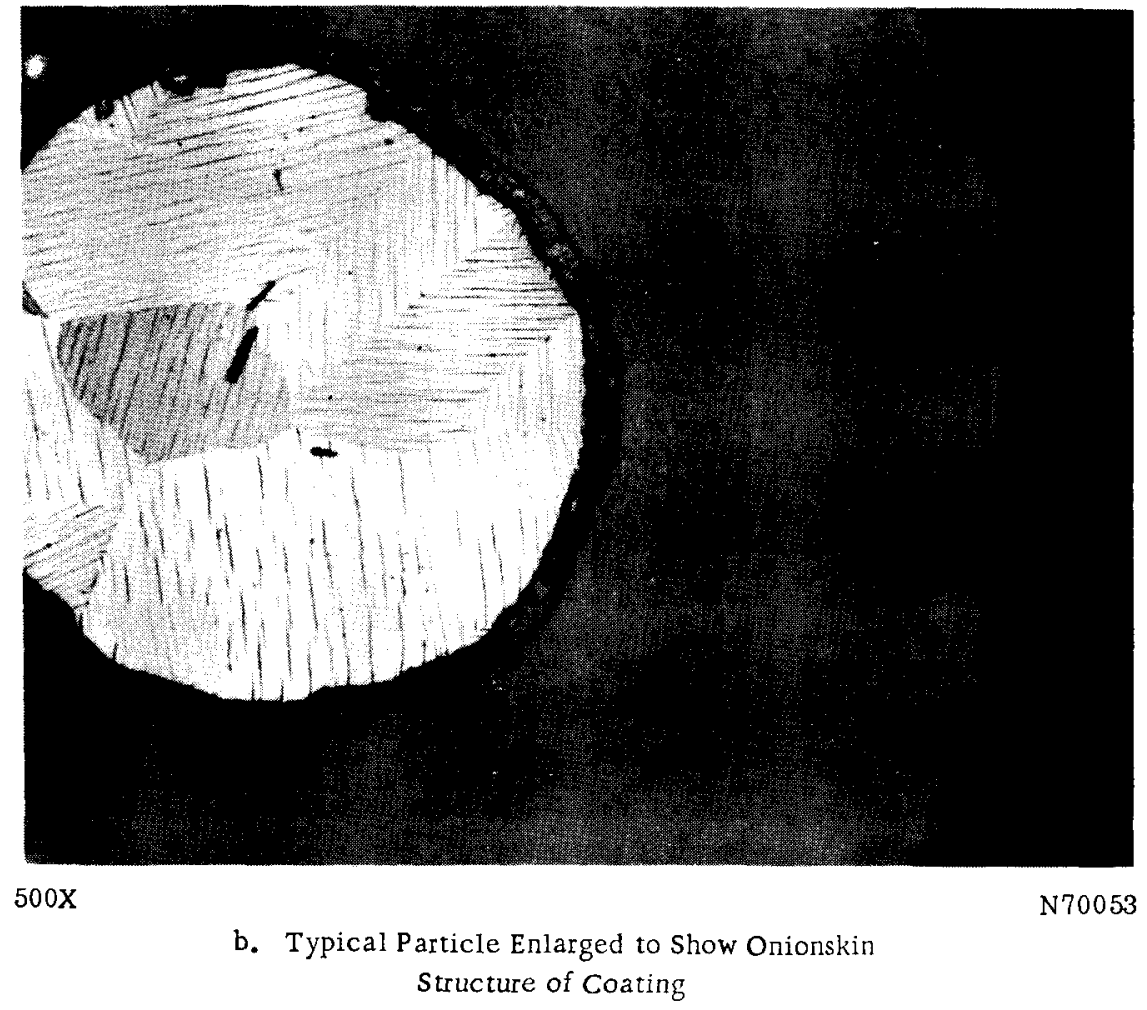

FIGURE 6. SECTIONS OF 150 TO $175-\mu$ UC $_{2}$ POWDER PARTICLES WITH 20- $\mu$ COATINGS OF PYROLYTIC CARBON 
TABLE 2. SUMMARY OF LABORATORY EVALUATIONS OF CARBON-COATED UC 2

\begin{tabular}{|c|c|c|c|c|c|c|c|c|c|}
\hline \multirow[b]{2}{*}{ Lot } & \multirow{2}{*}{$\begin{array}{l}\text { Fuel Particle } \\
\text { Diameter, } \mu\end{array}$} & \multirow{2}{*}{$\begin{array}{l}\text { Coating } \\
\text { Thickness, } \mu\end{array}$} & \multirow{2}{*}{$\begin{array}{c}\text { Deposition } \\
\text { Temperature, } \\
\text { C }\end{array}$} & \multirow[b]{2}{*}{ Treatment } & \multirow{2}{*}{$\begin{array}{c}\text { Xenon-133 } \\
\text { Released }^{(a)} \\
\text { per cent }\end{array}$} & \multirow{2}{*}{$\begin{array}{l}\text { Alpha Assay, } \\
\text { cpm per } \mathrm{g} \\
\text { of clad } \\
\text { particles }\end{array}$} & \multirow{2}{*}{$\begin{array}{c}\text { Uranium } \\
\text { Contamination (b), } \\
\text { mg } \\
\text { per g of clad } \\
\text { particles }\end{array}$} & \multicolumn{2}{|c|}{$\begin{array}{c}\text { Uranium Leached }{ }^{(c)} \text {, } \\
\text { per cent }\end{array}$} \\
\hline & & & & & & & & $1 \mathrm{Hr}$ & $7 \mathrm{Hr}$ \\
\hline \multirow[t]{4}{*}{ SPIC } & $177-250$ & 40 & 1100 & As prepared & & - & - & 0.004 & $<0.001(\mathrm{e})$ \\
\hline & & & & Neutron activated, $875 \mathrm{C}$ & $\begin{array}{r}4.6 \times 10^{-4} \\
(160 \mathrm{~min})\end{array}$ & - & - & - & - \\
\hline & & & & Neutron activated, $1090 \mathrm{C}$ & $\begin{array}{c}4.6 \times 10^{-4} \\
(93 \mathrm{~min})\end{array}$ & - & - & - & - \\
\hline & & & & Neutron activated, $1315 \mathrm{C}$ & $\begin{array}{l}4.8 \times 10^{-2} \\
(65 \mathrm{~min})\end{array}$ & - & - & - & - \\
\hline \multirow[t]{2}{*}{ SP2 } & $177-250$ & 17 & 1015 & As prepared & - & $244 \pm 7$ & 0.33 & 0.004 & $<0.001$ \\
\hline & & & & $2000 \mathrm{C}$ thermal cycles $(\mathrm{d})$ & - & $3680 \pm 3$ & 4.94 & - & - \\
\hline \multirow[t]{2}{*}{ SP5 } & $149-177$ & 160 & 1350 & As prepared & - & $1.9 \pm 1.3$ & 0.005 & 0.001 & $<0.001$ \\
\hline & & & & $2000 \mathrm{C}$ thermal cycles & -- & $21.4 \pm 3.7$ & 0.06 & 0.321 & 0.60 \\
\hline \multirow[t]{2}{*}{ SP6 } & $149-177$ & 80 & 1350 & As prepared & -- & $1.9 \pm 1.3$ & 0.005 & 0.009 & 0.001 \\
\hline & & & & $2000 \mathrm{C}$ thermal cycles & - & $65.6 \pm 5.2$ & 0.18 & - & -- \\
\hline
\end{tabular}

(a) Per cent of total in particles at beginning of heat treatment released in indicated time.

(b) Same basis as in Table 1 .

(c) $1: 1 \mathrm{HNO}_{3}$ at $90 \mathrm{C}$.

(d) Nine $20-$ min thermal cycles in argon between 300 and $2000 \mathrm{C}$.

(e) Detection limit is 0.001 per cent. 
Discussion

Question, L. R. Zumwalt (GA): Are the coated particles screened after vapor deposition of the carbon coating?

Reply:

Yes, not to break up agglomerates, but to remove soot and chips of carbon which may have broken loose from the reactor walls.

Question, R. Kirkpatrick (AEC): In the neutron-activation results with carbon-coated $\mathrm{UC}_{2}$ there appears to be some cracking of the coatings between 2000 and $2400 \mathrm{~F}$.

Reply:

That is correct. Some of the coatings have cracked. There is a large difference in the coefficients of expansion of the core and the coating which results in large tensile stresses in the coating as the particles are heated above the coating-deposition temperature.

Question, L. R. Zumwalt (GA): Is there appreciable adherence between the $\mathrm{UC}_{2}$ particles and the carbon coating?

Reply:

The fuel particle shrinks away from the coating when the coated particle is brought to room temperature. During metallographic preparation the carbon coating frequently chips off at the interface. These considerations suggest that the adherence, if any, is weak.

Question, C. Hoenig (Lawrence): Is the re uranium in the coatings?

Reply:

To minimize uranium contamination in our $\mathrm{Al}_{2} \mathrm{O}_{3}$ work for Sanderson \& Porter, we stop the coating process after a 5 to $8-\mu$ coating is deposited, remove the particles, leach them in nitric acid, and continue the coating process in a clean reactor.

Question, G. Tully (GA): Is the vapor feed at $1 \mathrm{~atm}$ ?

Reply: Yes.

Question, L. R. Zumwalt (GA): Did you have trouble with deposition on the wall?

Reply:

A small amount of $\mathrm{Al}_{2} \mathrm{O}_{3}$ forms on the wall. However, this does not appear to cause any difficulty.

Question, L. R. Zumwalt (GA): Have you ever coated irregularly shaped fuel particles?

Reply:

We prefer spheres, but we have coated nonspherical particles also. The coating is fairly uniform at the corners. 
Question, L. R. Zumwalt (GA): Have you worked with zirconium carbide?

Reply:

No, we have not investigated this coating. However, there are suitable reactions for the deposition of zirconium carbide, and the development of this coating should be feasible.

\section{Fuel-Element Fabrication}

W. C. Riley

Many of the fuel applications currently of interest involve the use of coated fuel particles dispersed in a suitable matrix. Graphite is the logical matrix choice for carbon-coated $\mathrm{UC}_{2}$, and $\mathrm{Al}_{2} \mathrm{O}_{3}$ or graphite is the choice for $\mathrm{UO}_{2}$ particles coated with $\mathrm{Al}_{2} \mathrm{O}_{3}$. Some exploratory work on pressing oxide-coated $\mathrm{UO}_{2}$ shows that the asproduced particles can be aggregated to form a pellet.

Our work on the fabrication and evaluation of bodies containing coated fuel particles has been limited.

\section{Graphite-Matrix Studies}

Graphite has been fueled with $\mathrm{Al}_{2} \mathrm{O}_{3}$-coated $\mathrm{UO}_{2}$ as part of our assistance program to Sanderson \& Porter. Most of the work has been done with bodies made with 2301 graphite powder and standard pitch. A few bodies containing Texas coke and standard pitch or AGOT graphite and a thermosetting resin have also been prepared. During fabrication of the bodies temperatures have been kept below $2300 \mathrm{~F}$ to prevent possible reaction between the graphite and the oxide coatings. Oxide loadings up to about 7.5 volume per cent are of interest in the Pebble-Bed Reactor. This latter loading does not constitute a limit on the amount of oxide that can be dispersed in graphite.

A brief study was undertaken to determine whether the presence of the coated particles changes significantly the properties of the graphite matrix. Compression tests were run on bodies containing about 7.5 volume per cent oxide in the form of $\mathrm{Al}_{2} \mathrm{O}_{3}$-coated $\mathrm{UO}_{2}$ and bodies containing the same amount of fuel (about 2 volume per cent) but no coating. Results indicate that the presence of the coated particles does not decrease compressive strength. Results reported by National Carbon are also of interest. Table 3 shows the effect of uranium oxide content on the physical properties of graphite. (3) Decreases in thermal conductivity, flexural strength, and compressive strength are small with fuel loadings as high as about $20 \mathrm{w} / \mathrm{o}$. 
TABLE 3. PROPERTIES OF MOLDED URANIUM OXIDE-BEARING GRAPHITE MATERIALS BAKED AT $1450 \mathrm{C}$ (3)

\begin{tabular}{cccccc}
\hline \multicolumn{2}{c}{$\begin{array}{c}\text { Uranium } \\
\text { Content }\end{array}$} & $\begin{array}{c}\text { Bulk } \\
\text { Density, } \\
\text { g per cm }\end{array}$ & $\begin{array}{c}\text { Thermal } \\
\text { Conductivity (a,b), } \\
\text { w/(cm)(K) }\end{array}$ & $\begin{array}{c}\text { Flexural(a) } \\
\text { Strength, } \\
\text { psi }\end{array}$ & $\begin{array}{c}\text { Compressive } \\
\text { Strength, } \\
\text { psi }\end{array}$ \\
\hline G per Cm ${ }^{3}$ & w/o & 0.22 & 6600 & 15,800 \\
0 & 0 & 1.72 & 0.20 & 5470 & 18,600 \\
0.067 & 3.8 & 1.75 & 0.17 & 5070 & 18,990 \\
0.220 & 11.7 & 1.88 & 0.18 & 4290 & 14,100 \\
0.384 & 19.9 & 1.93 &
\end{tabular}

(a) Measurements made against grain.

(b) Measurements made at room temperature.

In preparation for a capsule irradiation of a fueled-graphite body a specimen was evaluated by the following procedures:

(1) Radiography

(2) Alpha assays

(3) Neutron activation followed by postirradiation heating

(4) Thermal cycling

(5) Heat treatment followed by metallography.

Radiography showed that the particles were uniformly dispersed in the graphite. About $10^{-6}$ to $10^{-7}$ of the uranium in the body was on the surface. This amount of contamination was expected on the basis of an alpha assay of the as-produced particles. Additional alpha assays on fragments of the body after impact fracture showed that the coatings were not damaged when the body fractured. Neutron-activation results showed that the $\mathrm{Al}_{2} \mathrm{O}_{3}$ coatings retained fission gas. At the highest temperature $(2000 \mathrm{~F})$, the total release of xenon-133 from the body after several hours at this temperature was no greater than the amount observed in a neutron-activation test of particles alone. Thermal cycling the body several times between $2000 \mathrm{~F}$ and room temperature during the postirradiation heating did not increase fission-gas release. These tests demonstrate that the $\mathrm{Al}_{2} \mathrm{O}_{3}$ coatings are not damaged during the $2300 \mathrm{~F}$ heat treatment given the graphite body during fabrication.

The evaluation work reported above suggests that little or no reaction occurs between graphite and the $\mathrm{Al}_{2} \mathrm{O}_{3}$ coatings at the temperatures occurring during fabrication of the body $(2300 \mathrm{~F})$. At some higher temperature, less than $3000 \mathrm{~F}$, reaction will occur and damage the $\mathrm{Al}_{2} \mathrm{O}_{3}$ coatings. A brief investigation has been made of the time and temperature required for the reaction to take place. Figure 7 a shows aluminacoated $\mathrm{UO}_{2}$ dispersed in a $\mathrm{graphite}$ body fabricated at $2300 \mathrm{~F}$. The central white area is $\mathrm{UO}_{2}$ and the surrounding gray area is the coating. Figure $7 \mathrm{~b}$ shows the same specimen after a $1000-h r$ heat treatment at $2500 \mathrm{~F}$ in flowing helium. Longer times and higher temperatures have not been studied. Reaction between the coating and the 


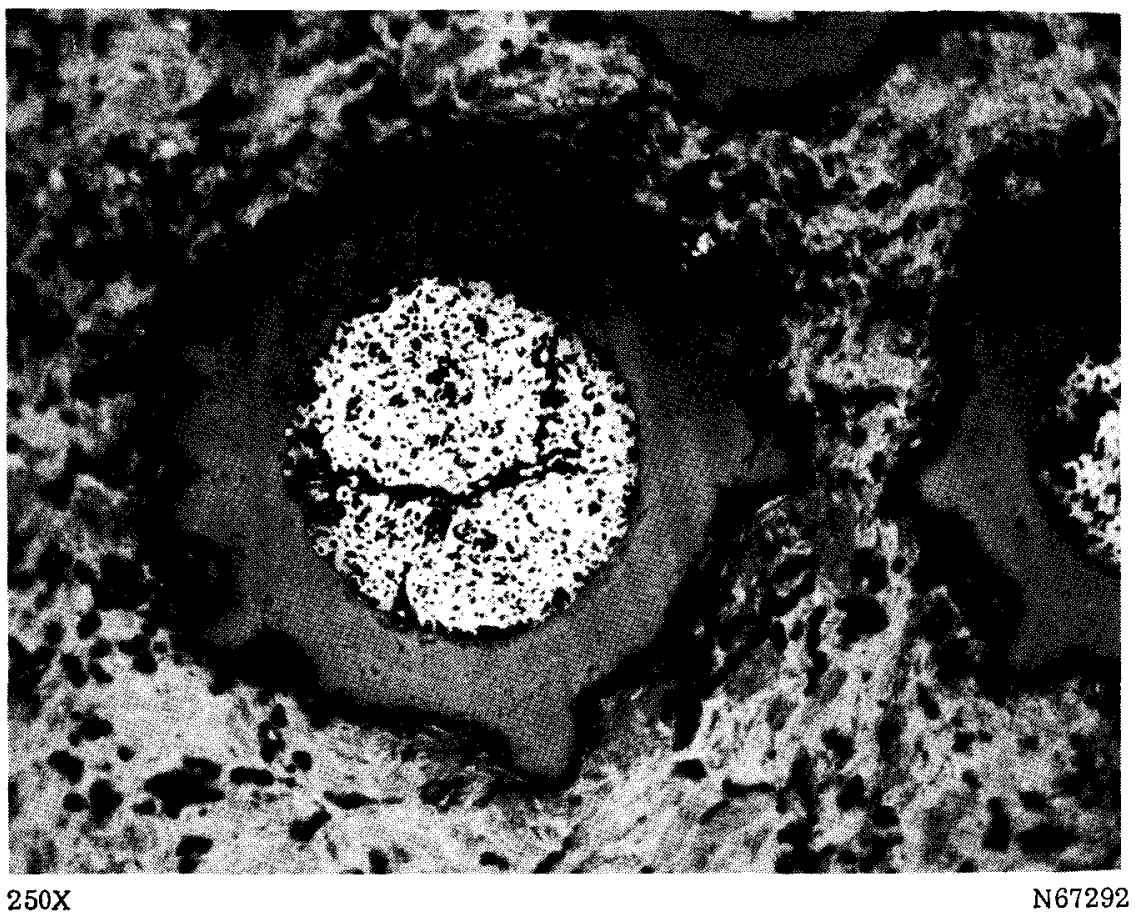

a. As Fabricated

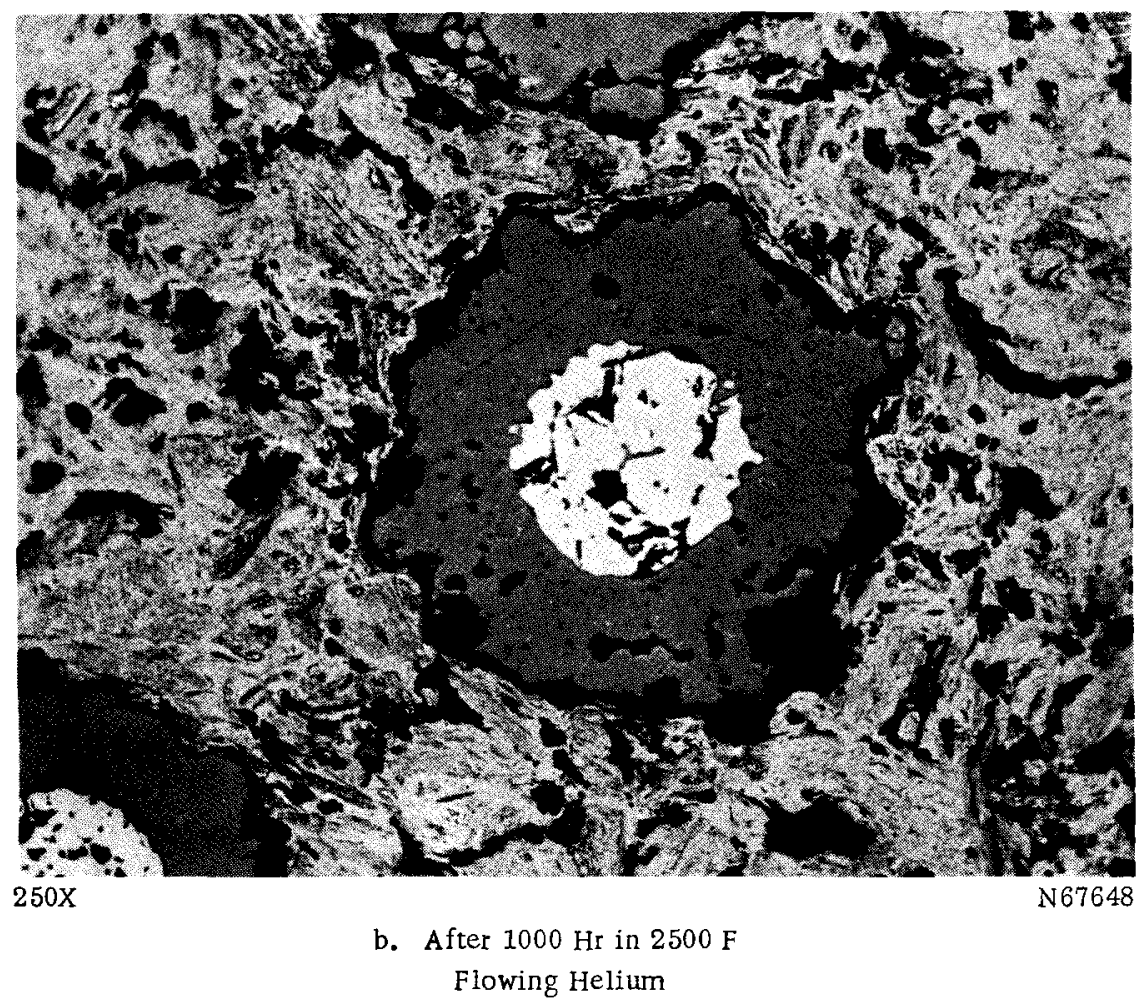

FIGURE 7. EFFECT OF HEAT TREATMENT ON $\mathrm{Al}_{2} \mathrm{O}_{3}$-COATED UO $\mathrm{O}_{2}$ PARTICLES DISPERSED IN GRAPHITE

Very little evidence of a reaction can be observed in the specimens. 
graphite is suggested by the voidlike appearance at the graphite-coating boundary in Figure 7b. The severity of the reaction between the coating and graphite depends on the location of the particle in the body. Generally, particles near or on the surface of the body show more coating deterioration than those inside the body. We have not investigated the effect of fabrication variables, degree of particle-graphite contact, and choice of graphite starting materials on the kinetics of reaction. All the se variables are expected to influence the course of the reaction.

In the limited work completed so far on graphite bodies containing $\mathrm{Al}_{2} \mathrm{O}_{3}$-coated $\mathrm{UO}_{2}$, encouraging results promise important high-temperature fuel-element applications. Two aspects require immediate attention: (1) determination of the maximum amount of oxide that can be dispersed in graphite without affecting the physical properties and (2) determination of the effect of chemical reaction between the coating and graphite on the fission-gas release.

\section{Oxide-Matrix Studies}

To date, studies on incorporation of coated particles in oxide matrices have been confined to preliminary work on fabrication techniques.

The preparation of dense oxide matrices containing coated fuel particles may be difficult with vapor-deposited coatings. These coatings are not readily sinterable, and when a ginterable matrix shrinks onto them, some cracking of the matrix is likely. There are several possible methods for solving this problem. One involves creating a suitable burned-out layer around the vapor-deposited particles that will accommodate the shrinkage of the matrix. A porous coating applied to the outside of a dense coating may have a similar effect. Both the fluidized-bed and spray-tumbling (1) methods of coating $\mathrm{UO}_{2}$ particles can provide tailored porosity in the coating and thus permit a matching of coating and matrix. Another approach is to aggregate the coated fuel particles themselves by hot-pressing techniques. Some preliminary trials have been made with $\mathrm{Al}_{2} \mathrm{O}_{3}$-coated $\mathrm{UO}_{2}$. It has been found that at $2800 \mathrm{~F}$ and $7000 \mathrm{psi}$, flow can be obtained in these vapor-deposited coatings. The resulting bodies maintain structural integrity, and their density is perhaps 90 per cent of theoretical. This fragmentary result is encouraging but additional work is required to establish the best fabrication method and the quality of the bodies.

\section{Discussion}

Question, R. Kirkpatrick (AEC): Do you have any results on the properties of the hotpressed $\mathrm{Al}_{2} \mathrm{O}_{3}$ body?

Reply:

No, this body was made only a few days ago. The body is spherical in shape, and contains about 80 per cent by volume of fuel.

\footnotetext{
* A few days later several hot-pressed bodles were heated in $1200 \mathrm{~F}$ air for several hours. These bodies were made by hotpressing 100 to $150-\mu \mathrm{UO}_{2}$ coated with $40 \mu$ of $\mathrm{Al}_{2} \mathrm{O}_{3}$. Hot-pressing temperatures and pressures up to $2900 \mathrm{~F}$ and 7000 psi were used. The porosities of the bodies, determined by liquid displacement, ranged from 20 to 1 per cent. All the bodies crumbled to a fine powder in this oxidation test. In fabricating these bodies, pressure was applied before the compact reached temperature. It is probable that oxidation-resistant bodies can be made by heating the compacts before applying pressure.
} 
Question, L. Zumwalt (GA): Can fuel pellets $1 / 2$ in. in diameter be coated?

Reply:

It appears possible to coat a pellet this large but abrasion is expected to be a difficult problem.

$\underline{\text { In-Pile Tests }}$

G. E. Raines

Based on the encouraging results of the out-of-pile evaluation of $\mathrm{Al}_{2} \mathrm{O}_{3}$-coated $\mathrm{UO}_{2}$ and graphite fueled with the se particles, irradiation of a fueled-graphite sphere in the BRR was initiated in early April, 1960. This capsule experiment was carried out in support of Sanderson \& Porter's fuel-element evaluation program for the Pebble-Bed Reactor. In the following discussion the purpose and results of this capsule experiment will be reviewed.

\section{$\underline{\text { SP-5 Capsule Experiment }}$}

The purpose of the SP-5 experiment is to determine the effect of burnup on the high-temperature in-pile release of short-lived and long-lived fission gases from a number of fueled-graphite spheres of interest in the Pebble-Bed Reactor program. Structural and physical changes in the spheres will be determined by postirradiation examination on completion of the irradiation. The capsule is a so-called sweep capsule. Fission gases are carried out of the capsule by a once-through stream of helium at low pressure and low flow rate. A continuous flow of helium passes over the spheres during irradiation. Long-lived fission gases in the helium are measured by gammaspectrometry methods after collection of a known fraction of the exit helium flow in charcoal traps above the pool of the BRR. Short-lived fission gases are determined by shunting the exit helium through a tube packed with stainless steel cloth. During the $90-\mathrm{sec}$ residence time of the helium in the tube (daughter trap), short-lived fission gases decay and deposit long-lived gamma-emitting daughters. Radiochemical analysis of the daughter trap provides the necessary information for the calculation of the rate of escape of the short-lived precursors from the sphere. The following fission-gas species have been measured in the sweep helium:

\begin{tabular}{|c|c|c|c|}
\hline \multicolumn{2}{|c|}{ Long - Lived } & \multicolumn{2}{|c|}{ Short-Lived } \\
\hline Species & Half-Life & Species & Half-Life \\
\hline Krypton $-85 m$ & $4.4 \mathrm{hr}$ & Xenon-135 & $9.2 \mathrm{hr}$ \\
\hline Krypton -87 & $78 \mathrm{~min}$ & Krypton -89 & $3.2 \mathrm{~min}$ \\
\hline Krypton -88 & $2.8 \mathrm{hr}$ & Xenon-140 & $16 \mathrm{sec}$ \\
\hline Xenon-133 & 5.2 day & Xenon-141 & $1.7 \mathrm{sec}$ \\
\hline
\end{tabular}

Iodine-131 and iodine-133 are also observed in the daughter trap. Other fission-gas species are undoubtedly present in the sweep helium but no thorough search for additional species has been made. Half-life considerations, decay properties, and fission yields restrict the number of species which can be easily assayed in the gas or in the daughter trap. 
Figures 8 and 9 show the SP-5 capsule and the gas train for assay of long-lived fission gases in the exit helium. The daughter trap (not shown) is located above the capsule and is in parallel with the exit line from the capsule. Figure 10 shows a photograph of the assembled capsule and daughter traps. Fission heat is the only source of heat in the capsule. The capsule contains six fueled 1.5-in.-diameter graphite spheres, two sweep specimens and four static (no helium flow) specimens, mounted in hollowedout graphite blocks. The sweep helium passes through the thin spherical annulus separating the sphere from the graphite block. This annulus is filled with graphite powder. Thermocouples positioned in the graphite blocks in the two sweep compartments record temperatures. Heat-transfer considerations allow us to estimate sweep-specimen temperatures from the thermocouple data. The graphite sphere fueled with $\mathrm{Al}_{2} \mathrm{O}_{3}-$ coated $\mathrm{UO}_{2}$ is located at the top of the capsule. An identical sphere is also being irradiated in the static compartment. The remaining four spheres contain bare fuel particles and will not be discussed this morning.

The 1.5-in.-diameter graphite sphere fueled with $\mathrm{Al}_{2} \mathrm{O}_{3}$-coated $\mathrm{UO}_{2}$ particles is designated FA-22, No. 471. Coating thickness is $40 \mu$. This sphere contains about $4.7 \mathrm{~g}$ of fully enriched $\mathrm{UO}_{2}$ in a total of about 500,000 coated particles. The sphere was heated to a maximum temperature of $2300 \mathrm{~F}$ during fabrication. Heat-generation rate is $1.5 \mathrm{kw}$ in an effective flux of about $1013 \mathrm{nv}$. Sphere-surface and-center temperatures are running about 1300 and $1500 \mathrm{~F}$, respectively. Thermocouple data during a typical BRR cycle (Figure 11) are corrected for the temperature drop across the graphite block and annulus to give the se latter estimates. Figure 11 also shows the the rmocouple history of the second sweep specimen which is of no interest here. As of July 8, 1960, the FA-22 sphere has accumulated a 70-day irradiation exposure for an estimated uranium-235 fission burnup of about 3 per cent.

$\underline{\text { Results }}$

We express the measured release of both the long- and short-lived fission gases by the term $R / B$, where $R$ is the rate of release of a given fission-gas species from FA-22 in atoms per second and $B$ is the equilibrium rate of production of this species in the sphere in atoms per second. The value of $B$ is calculated from the neutron flux, fission yield, uranium-235 fission cross section, and uranium-235 content. The R/B value is a particularly good index to use in describing the fission-gas-release results because, when radioactive equilibrium is achieved both inside and outside a fuel specimen, $R / B$ is the ratio of the number of curies outside the specimen to the number inside the specimen. Accordingly, R/B values express directly the amount of contamination which this fuel specimen contributes in a closed system. Another interpretation of $R / B$ is simply the fraction of power from a fissioning source which is effective in liberating fission products. For example, if $R / B$ is $10^{-6}$ for a 1 -megawatt fission source, the effective fission-product source is $1 \mathrm{w}$.

Figure 12 shows a partial history of R/B values for the graphite sphere containing $\mathrm{Al}_{2} \mathrm{O}_{3}$-coated $\mathrm{UO}_{2}$ particles. Sphere-surface temperature is indicated above each point. There is some scatter in the points for individual species, so we have omitted krypton-87, krypton-88, and xenon-133 to simplify the figure. The se latter three species show a long-term variation similar to those for krypton-85m and xenon-135. Figure 12 does not include the R/B values from the most recent gas sample (70 days), which fall in the $10^{-6}$ region. The solid points are the $R / B$ values for the three listed short-lived species. These latter data are discussed below. During the first 20 days of irradiation there appeared to be a correlation between $R / B$ and temperature, but this 


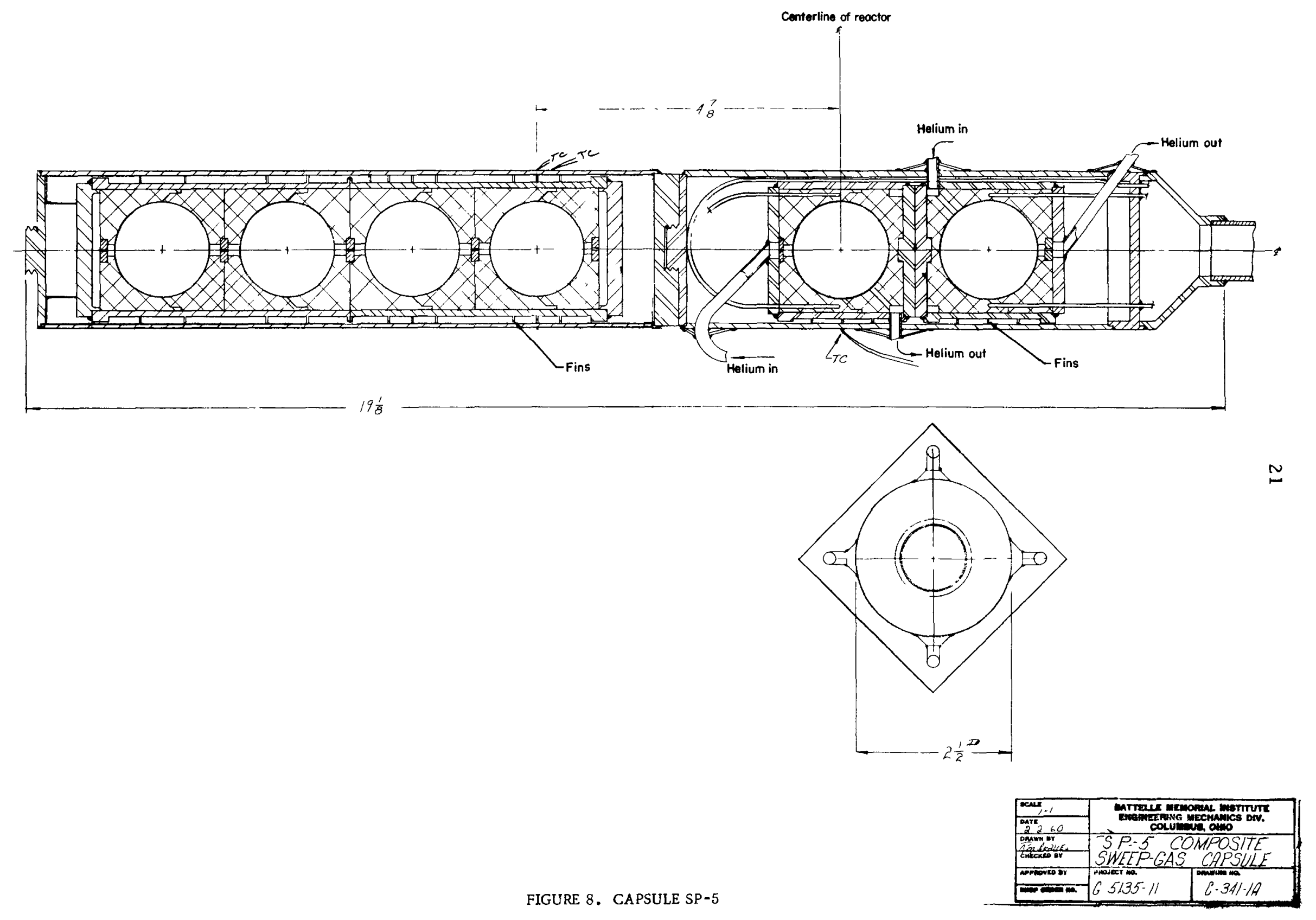




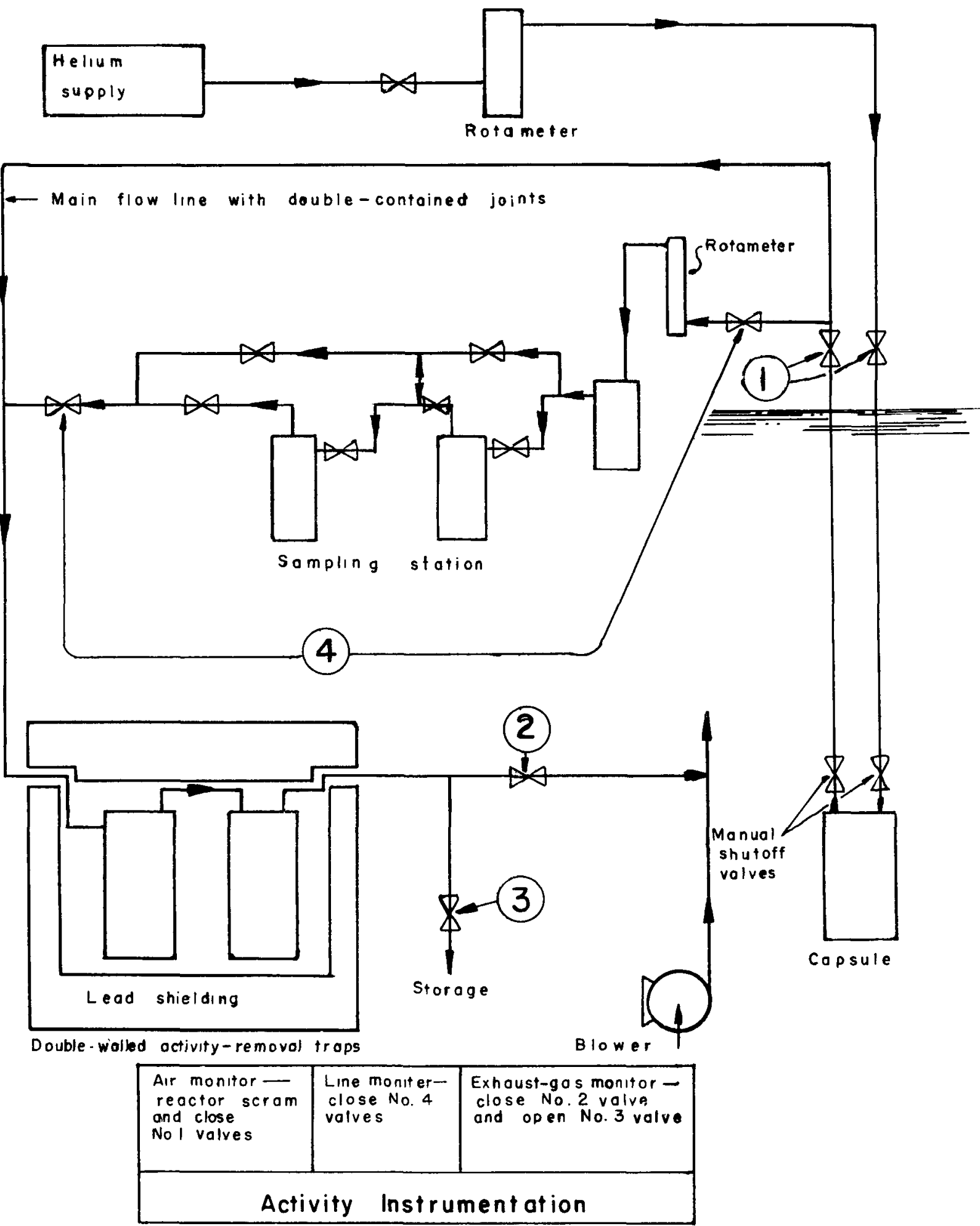

FIGURE 9. GAS TRAIN FOR SP-5 CAPSULE EXPERIMENT 


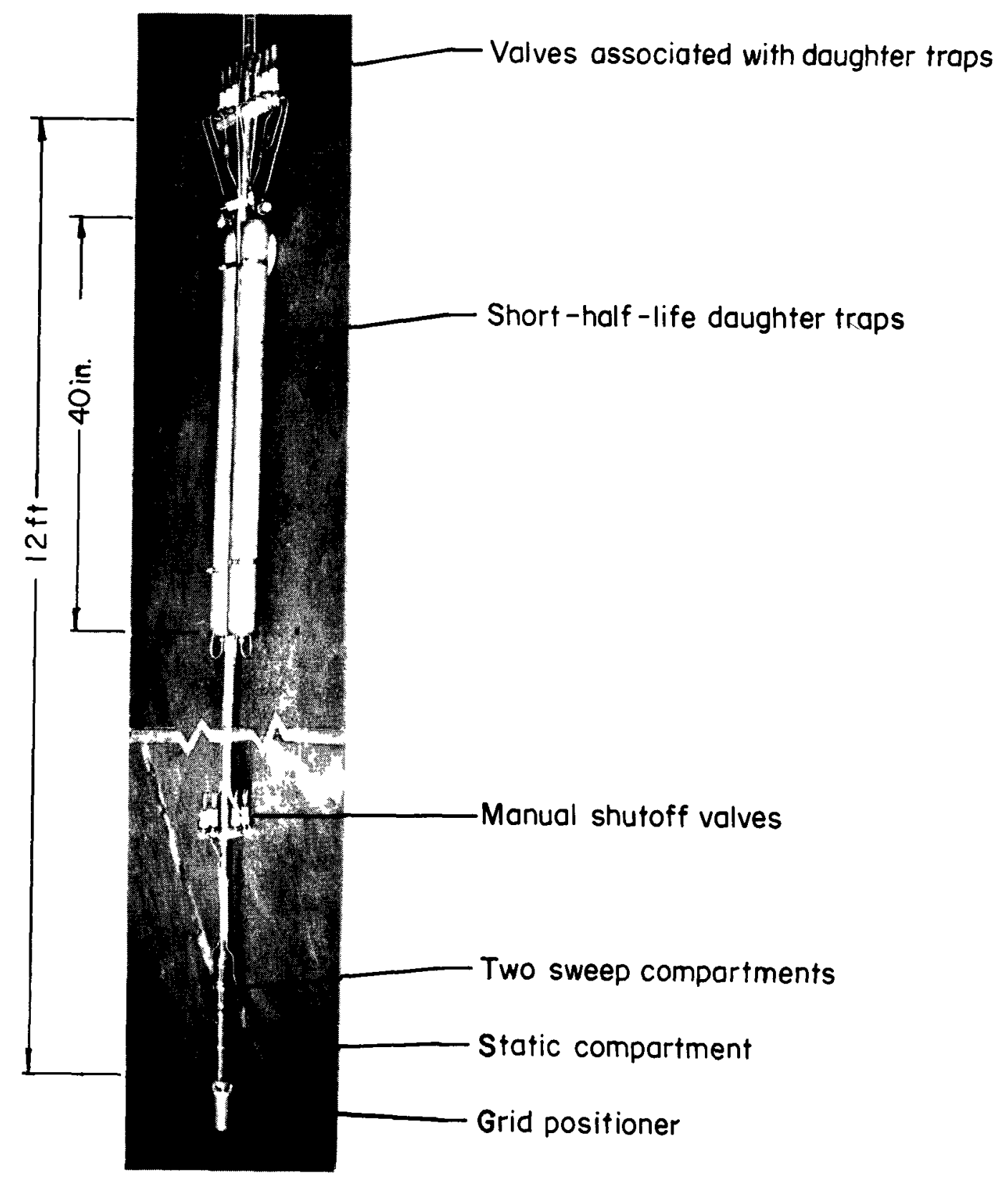

FIGURE 10. ASSEMBLED SP-5 CAPSULE WITH DAUGHTER TRAPS 


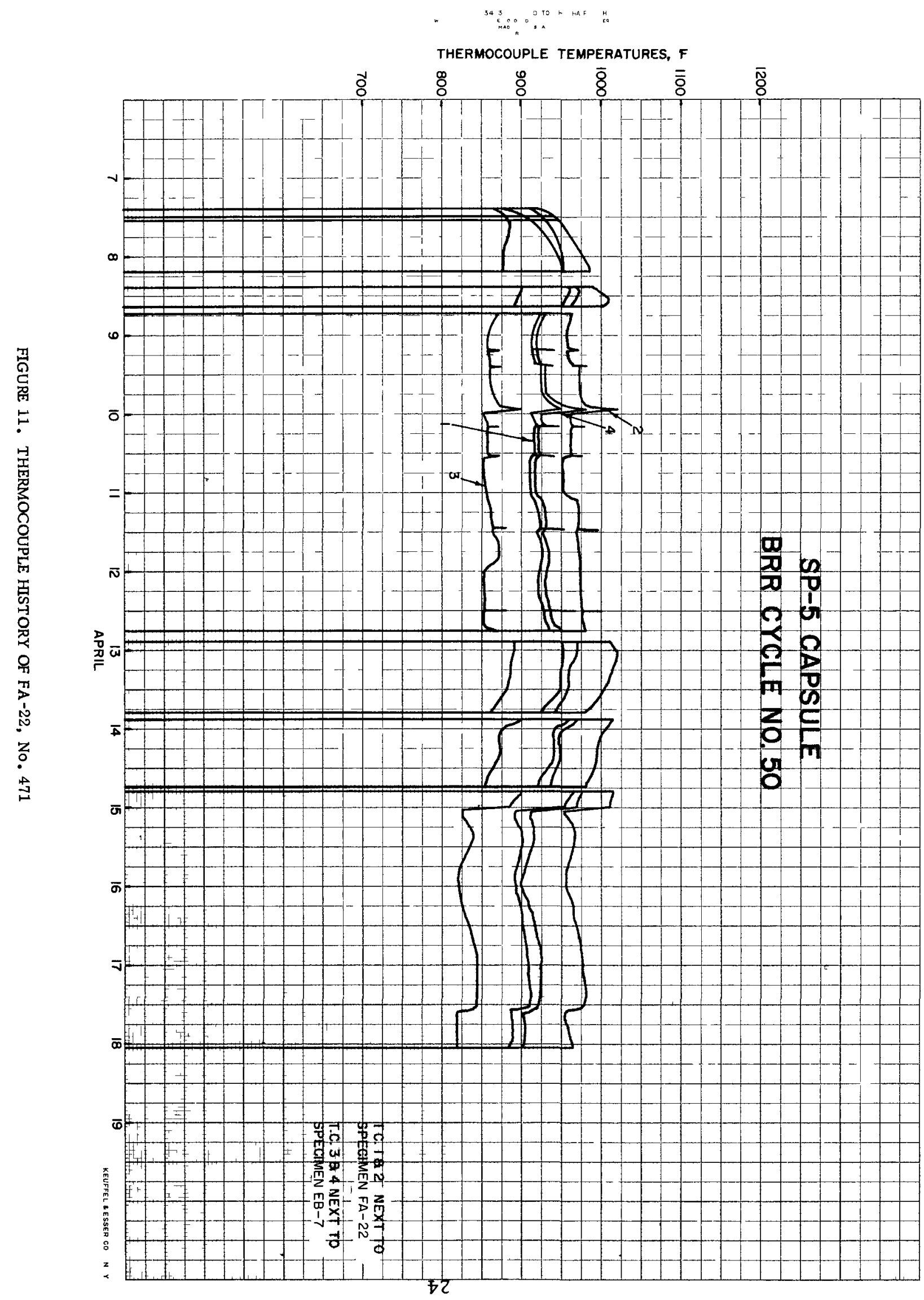




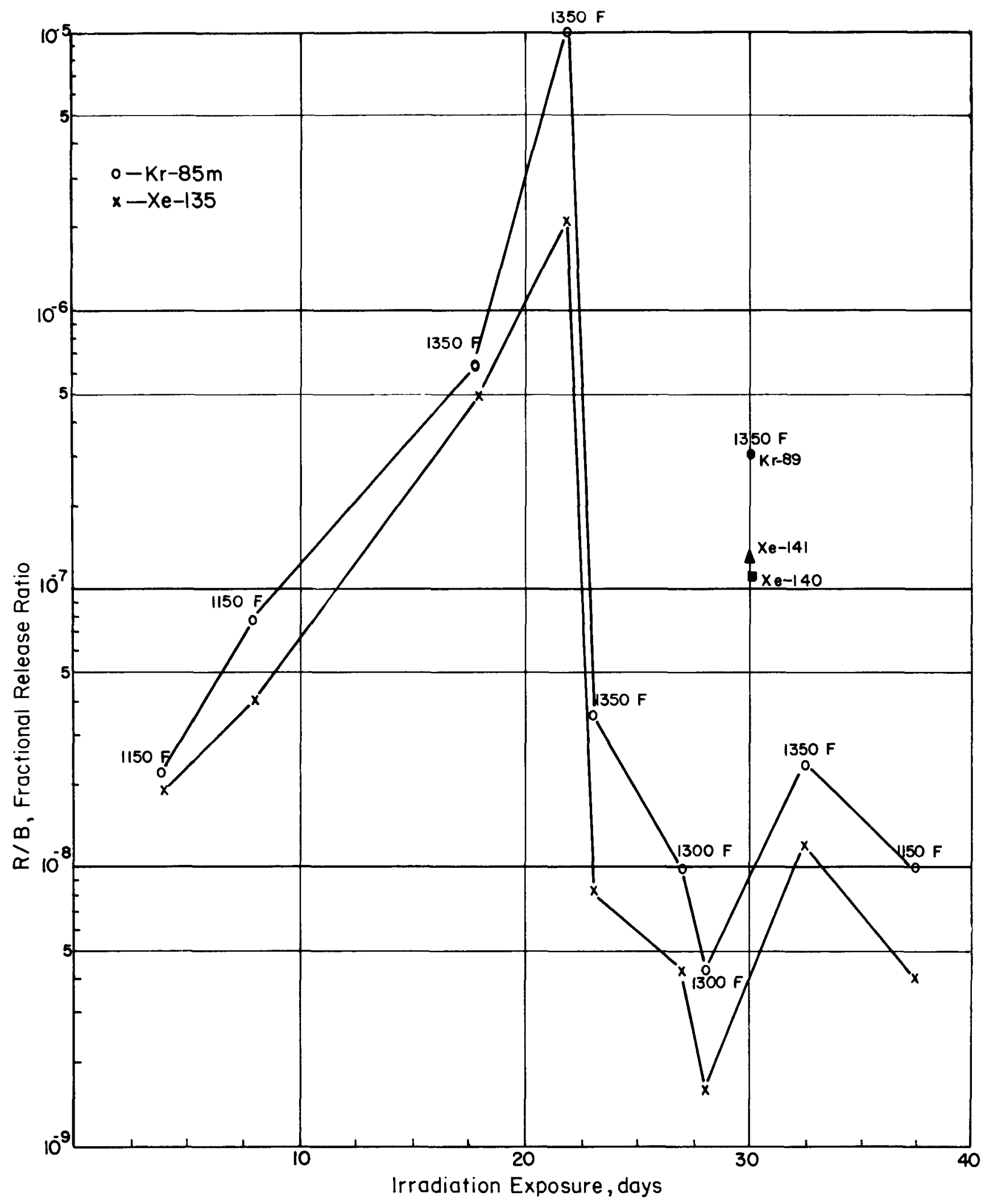

FIGURE 12. HISTORY OF FISSION-GAS RELEASE FROM FA-22 
was not verified by the subsequent $R / B$ values. The $R / B$ values from two successive gas samples collected on the same day show agreement within a factor of two. Examination of Figure 12 shows that fission-gas retention in the $\mathrm{Al}_{2} \mathrm{O}_{3}$-coated $\mathrm{UO}_{2}$ particles is excellent.

Four species, barium-140, cerium-141, iodine-131, iodine-133, and strontium89, together with traces of cerium-137 and tellurium-132, we re found in the daughter trap after the exit helium had passed through the trap for $24 \mathrm{hr}$. Barium-140, cerium141 , and strontium -89 are deposited in the trap when their short-lived precursors, xenon-140, xenon-141, and krypton-89, respectively, decay in the trap. Figure 13 summarizes the results for barium-140, cerium-141, and strontium-89. If the only source of these three species is decay of xenon-140, xenon-141, and krypton-89, respectively, and if all daughters stick where they are formed, the straight lines give the expected distributions for a 90-sec residence time of the helium in the trap. The experimental points are in excellent agreement with the predicted distributions. Iodine results are shown in Figure 14. The tails of the distributions for iodine-131 and iodine -133 are probably the result of poor counting statistics. The R/B values for iodine-131 and iodine-133 are difficult to estimate because the fraction of iodine liberated from the sphere which enters the trap is not known. Assuming that all of it is collected in the trap gives $R / B$ values of about $10^{-8}$ for both iodine species. Daughtertrap activity is compared with the activity in the FA-22 sphere in Table 4.

TABLE 4. SUMMARY OF DAUGHTER-TRAP RADIOACTIVITY

\begin{tabular}{lcc}
\hline \hline Species & \multicolumn{2}{c}{ Radioactivity, curies } \\
\cline { 2 - 3 } Strontium-89 & $2.4 \times 10^{-7}$ & FA-22(a) \\
Barium-140 & $3.1 \times 10^{-7}$ & 64 \\
Cerium-141 & $5.0 \times 10^{-8}$ & 37 \\
Iodine-131 & $4 \times 10^{-8}$ & 37 \\
Iodine-133 & $1 \times 10^{-7}$ & 97 \\
\hline \hline
\end{tabular}

(a) Total activity collected in trap during 23 -hr period.

Prior to the SP-5 experiment Steve Beck of Battelle developed a theoretical diffusion model describing the release of a decaying fission gas from coated fuel particles. Figure 15 shows a plot of $R / B$ versus $\lambda$, the decay constant, for diffusion constants of $10^{-11}$ and $10^{-12} \mathrm{~cm}^{2}$ per sec in $\mathrm{UO}_{2}$ and $\mathrm{Al}_{2} \mathrm{O}_{3}$. Krypton and xenon are assumed to have the same diffusion constant in both materials. The solid curves are predicted by the model. Our experimental data are shown also, the vertical lines indicating the range of $\mathrm{R} / \mathrm{B}$ values for the long-lived gases. The single points are the $\mathrm{R} / \mathrm{B}$ values from the daughter trap. Experimental R/B values do not decrease rapidly with decreasing $\lambda$ as predicted by the model. 




FIGURE 13. DISTRIBUTION OF RADIOACTIVITY IN DAUGHTER TRAP FOR FA -22 


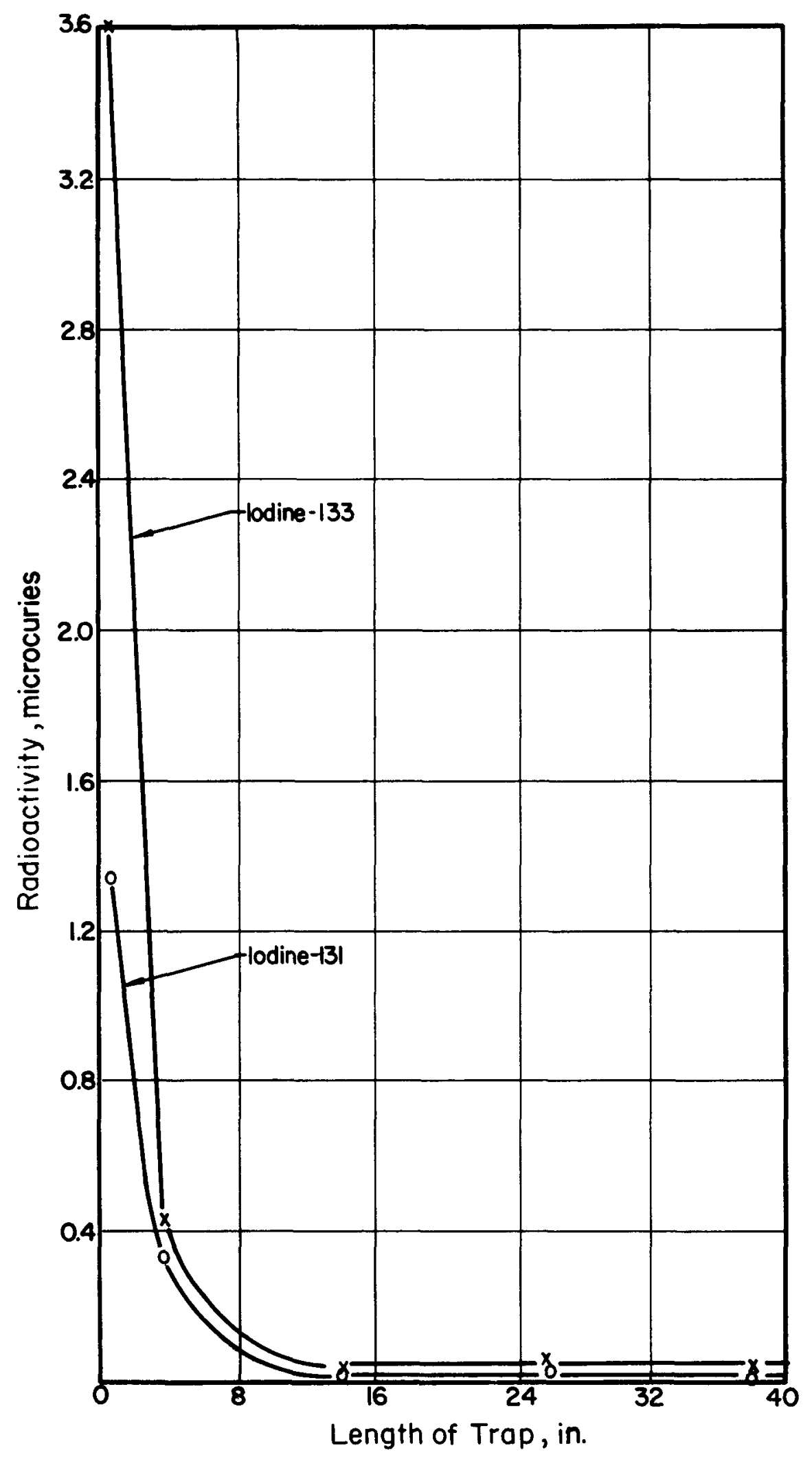

FIGURE 14. DISTRIBUTION OF IODINE RADIOACTIVITY IN DAUGHTER TRAP FOR FA -22 


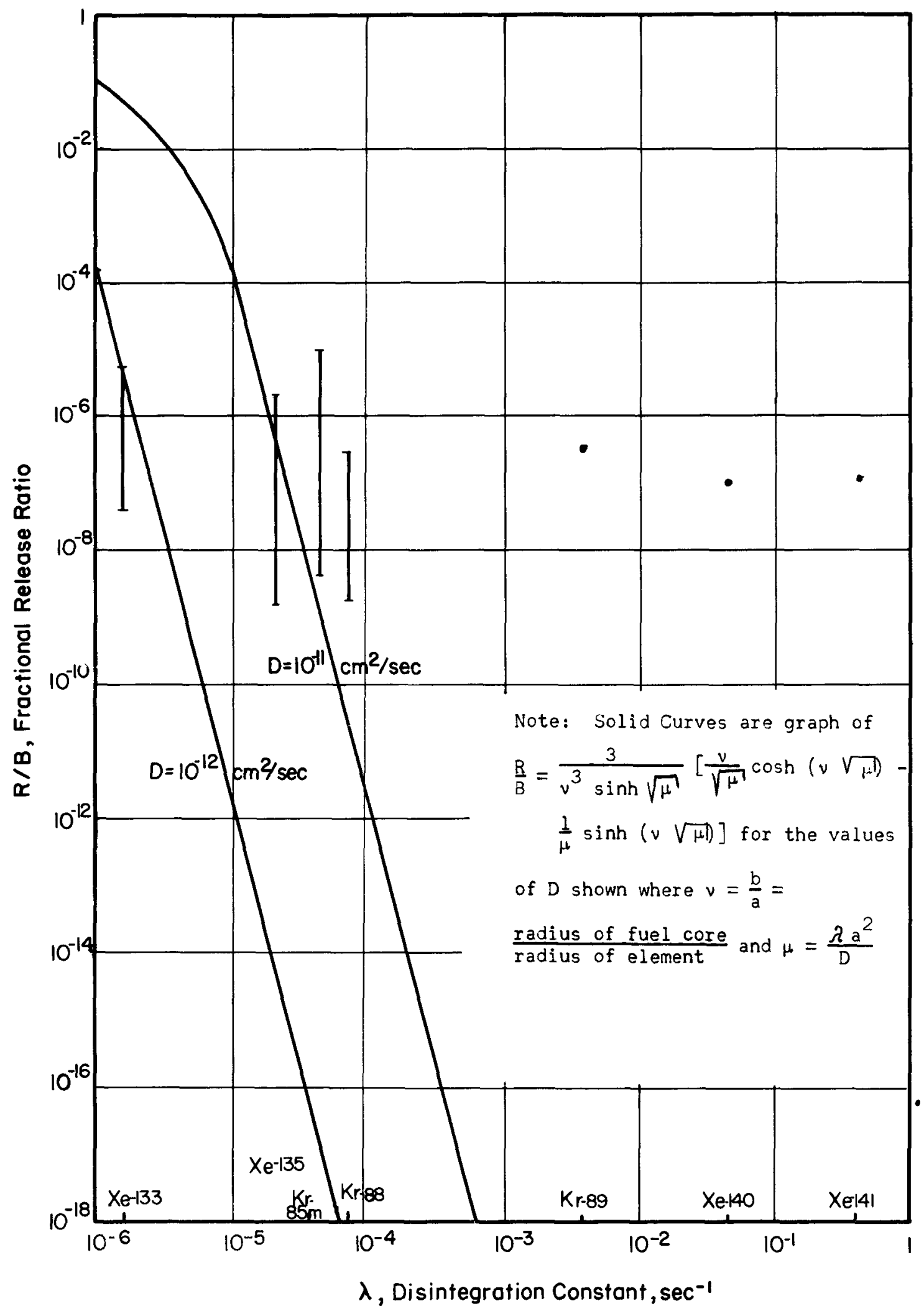

FIGURE 15. FRACTIONAL RELEASE RATIO VERSUS DISINTEGRATION CONSTANT 
At present, we believe that the major part of the observed fission-gas release from FA-22 is the result of uranium contamination on or close to the sphere surface. Fission gases generated in the contamination would be expected to pass freely out of the porous graphite with little effect of half-life on R/B. A measurement of the alpha radioactivity on the surface of the FA-22 sphere before irradiation gives a value of

$10^{-6}$ to $10^{-7}$ for the fractional amount of uranium in the sphere which is on the surface. If this contamination is the major source of fission gas in the sphere, the expected R/B is $10^{-6}$ to $10^{-7}$. The alpha assay gives, therefore, some support to our belief that a major source of the observed fission-gas release is the result of uranium contamination. This interpretation of the $R / B$ values and the absence of a strong half-life effect does not, however, explain the variation of $R / B$ values (Figure 12) with time.

Present plans are to continue the SP-5 experiment through October, 1960.

\section{Final Remarks}

\section{W. S. Diethorn}

In our presentation this morning covering the coated fuel-particle development the merit of $\mathrm{Al}_{2} \mathrm{O}_{3}$-coated $\mathrm{UO}_{2}$ has been demonstrated at moderately high temperatures, and the exploratory results with carbon-coated $\mathrm{UC}_{2}$ look promising. However, it is evident how very little is really known about the properties and behavior of coated particles, alone or in a matrix. The limitations of either of the two coated particles are undefined. Defining these limitations is the first step in the design of the optimum coated fuel particle for a specific fuel-element application.

It is appropriate here to discuss briefly a few of the major unknowns which are ahead in the development of the coated-fuel-particle concept. This is particularly desirable with $\mathrm{Al}_{2} \mathrm{O}_{3}$-coated $\mathrm{UO}_{2}$ because this coated particle has been advanced rapidly to the irradiation stage with good results but with only a modest understanding of its limitations.

In general, any coating on a fuel particle is expected to leak fission products at some combination of temperature and burnup. Leakage may result from the buildup of fission-gas pressure, damage to the coating by fission recoils, or both. Coating and fuel-particle properties are expected to influence these two types of failure but, at present, little is known about how these properties affect the behavior of the coated particle. Some leakage of fission gases will be tolerable if the leakage is entirely the result of diffusion through a mechanically sound coating. Under the se conditions shortlived fission gases will decay in the coating, reducing the amount of contamination from this parent source of long-lived fission-product gamma emitters.

One of the important applications of coated fuel particles is in a graphite matrix. From the exploratory carburization studies completed with $\mathrm{Al}_{2} \mathrm{O}_{3}$-coated $\mathrm{UO}_{2}$ in graphite there is evidence that the se coatings will not be suitable for long time service at temperatures over $3000 \mathrm{~F}$. Other oxide coatings may have higher temperature capabilities in graphite. Carbon-coated $\mathrm{UC}_{2}$ particles avoid the graphite-compatibility problem characteristic of the oxide coating, but at some temperature, fuel migration through the coating may limit high-temperature service. Anisotropy in the carbon coating may have a detrimental effect on irradiation performance. It is not known whether fission product diffusion is sensitive to this property of carbon coatings. 


\section{REFERENCES}

(1) Smalley, A. K., Riley, W. C., and Duckworth, W. A., "Alumina-Clad $\mathrm{UO}_{2}$ for Fuel Applications", BMI-1321 (February 18, 1959).

(2) "Design and Feasibility Study of a Pebble Bed Reactor - Steam Power Plant", NYO-8753 (May 1, 1958).

(3) Eatherly, W. P., Janes, M., Mansfield, R. L., Bourdeau, R. A., and Meyer, R. A., "Physical Properties of Graphite Materials for Special Nuclear Applications", Proceedings of the Second United Nations International Conference on the Peaceful Uses of Atomic Energy, Geneva (1958), Vol 7, A/Conf. 15/P/708, pp 389-401.

WSD:ims/pa 